\title{
A Review on the Emergence of Graphene in Photovoltaics Industry
}

\author{
Peetam Mandal ${ }^{1}(\mathbb{D})$, Jhuma Debbarma ${ }^{1} \mathbb{D}$, Mitali Saha ${ }^{1, *} \mathbb{( \mathbb { D }}$ \\ 1 Department of Chemistry, National Institute of Technology Agartala, Tripura - 799046, India \\ * Correspondence: mitalichem71@gmail.com (M.S.);
}

Scopus Author ID 55779373600

Received: 5.03.2021; Revised: 1.04.2021; Accepted: 3.04.2021; Published: 7.04.2021

\begin{abstract}
Graphene is considered one of the most significant materials of contemporary time, establishing a high impact in every research field domain and recently setting foot in the commercial market. The exclusive characteristics have made it one of the essential materials for many energy generating devices. Before using graphene electrodes, lithium was mostly used by energy-producing devices, but after the graphene invention, the electrode situation changed. Lithium-ion batteries are now getting attached to graphene electrodes to increase the device's efficiency and energy production rate. This review comprehensively covers the present scenario of leading graphene industries entering the photovoltaics market and highlighting the pristine futuristic vista where it might reign as a chief component in most energy devices. The light weightiness, cost-effective fabrication charge than other 2D materials is more promising for assembling in solar cell industries. It has also spread over benchmark prototypes in solar cars, space crafts, robotics, and artificial intelligence. The article also canvassed the science behind its mechanism in photovoltaics as well as emphasized ingenious modifications by several research institutions and conglomerate industries to exploit this wonder material for the welfare of humankind.
\end{abstract}

Keywords: graphene; solar cells; industries; photovoltaics; futuristic gadgets; renewable energy.

(C) 2021 by the authors. This article is an open-access article distributed under the terms and conditions of the Creative Commons Attribution (CC BY) license (https://creativecommons.org/licenses/by/4.0/).

\section{Introduction}

The ubiquitous influence of excessive energy demand can be observed by depleting natural resources and colossal demand on renewable energy resources [1,2]. The use of renewable resources over carbon-emitting natural fossil fuels helps minimize greenhouse gas emissions, excessive expanse to buy and process fossil fuel, and a speedy extinguishing source of natural fossil fuels [3]. Despite various renewable energy assets available, solar energy limitations are comparatively less than other alternatives, making it one of the cleanest and holistic energy sources to practice during this global energy crisis.

In one day, 164 watts per square meter is the entire sunlight hitting the earth's surface, thus having an immense impact in producing renewable energy resources [4]. The procedures of radiation, convection, photosynthesis, and various types of precipitation associated with the hydrological cycle hastens with the gargantuan quantity of sunlight falling on the earth, as depicted in Figure 1. In the long run, it increases the production of biofuels, photovoltaic and solar energy, and wind energy and hydroelectricity generation. Hence, the amount of sunlight hitting the earth's surface has a much important impact on renewable energy production. This harvested solar energy in countless solar farms relies on solar cell devices where performance 
is countered on solar cell efficiency (i.e., the amount of energy that gets collected from sunlight and converted into electricity using photovoltaics). Some leading solar panel-making manufacturers rely on the conventional usage of silicon solar cells, while the R\&D section of several franchises is exploring new specific materials over the last 5 years as an alternative for silicon [4]. Its different parts get constructed with new-age materials like perovskite, which are mainly used for light-absorbing substance in the solar panels. On the other hand, hole transportation is also necessary for getting proper electric output from the solar cell. Hence, nickel, lithium, and titania are the substances that usually get used in the solar cell for this purpose, whereas [6, 6]-Phenyl-C61-butyric acid methyl ester (PCBM) is mainly used as an electron transporting agent in the solar panels [5].

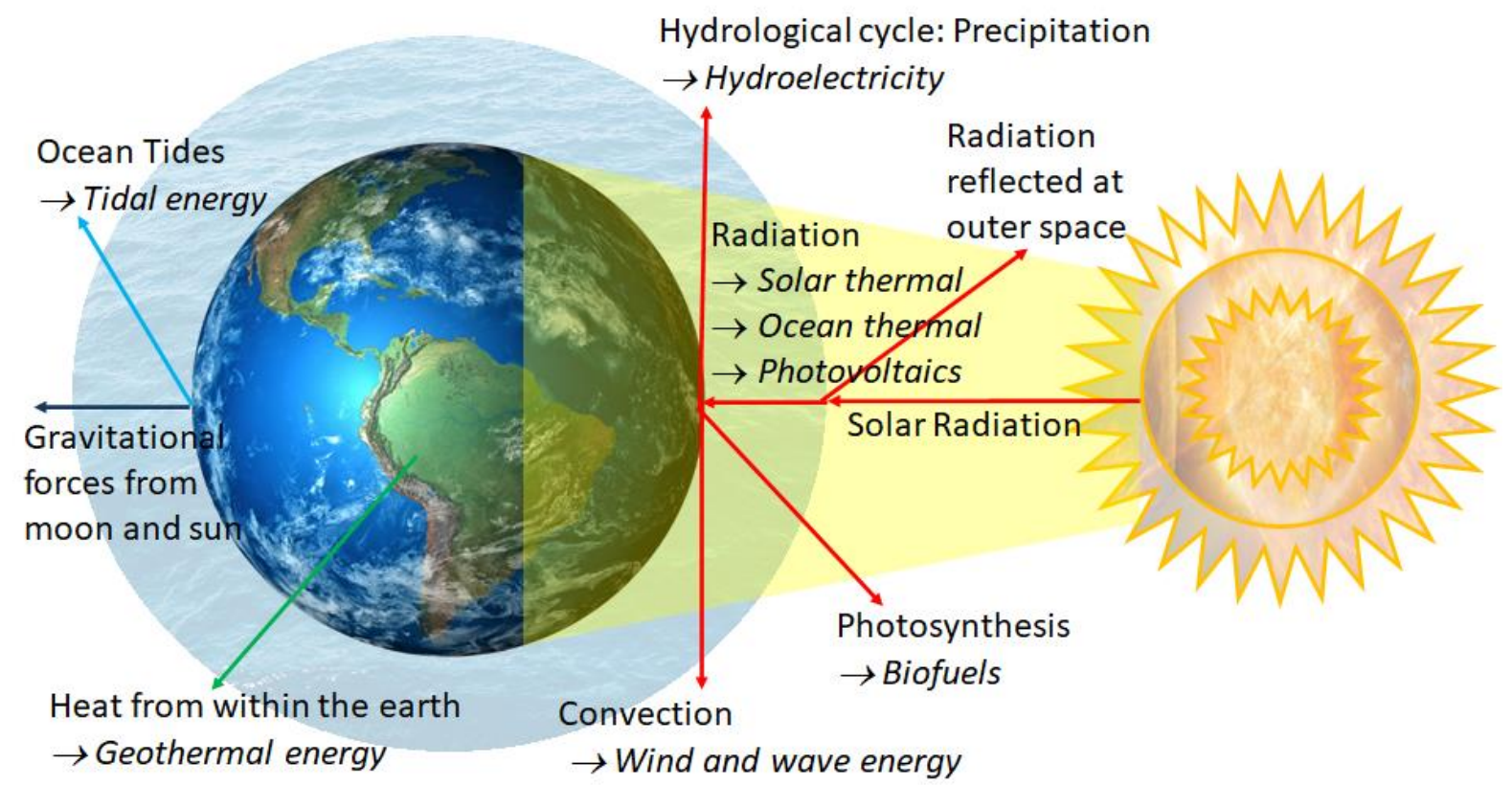

Figure 1. Formation of various renewable energy on earth by solar radiation.

In 2004, Andre Geim and Kostya Novoselov from Manchester University, while clearing a lump of graphite from a lamp, serendipitously discovered a new allotrope of carbon, having a hexagonal lattice of an atomistic thin single layer of carbon atoms known as graphene [6]. The thin layer of substance suddenly caught their attention, and the flakes were only one atom thin. This particular work won Andre and Kostya's Nobel Prize in 2010, displayed in figure 2. However, the realm of applications plunged to a great depth after discovering graphene varying from fuel additives to photonics and raised a question on the fight against COVID-19 [7-15]. Over 20graphene-based products had gained momentum in commercialization, and in recent years the photovoltaic industries were not left untouched [16].

Graphene had been blended with other chemical entities to enhance solar cell efficiency but subsequently hampered the solar cell device's reproducibility. However, in inverted solar cells, graphene oxides are mainly used as hole conductors paired with the solar cell's lightabsorbing materials. To get this advantage from the solar cell, graphene oxide had been fabricated with polymeric substances for fecund outcome [17-19]. Therefore, usage of graphene and its derivatives in solar cells adds up various positive outcomes in energy generation procedure, yet the fabrication process is quite challenging in graphene-based solar cells [20]. Apart from the challenging aspect of preparing a bulk amount of graphene, the installation time is reduced for other device components. On the other hand, incorporating graphene improves the overall performance of solar energy-producing devices. Interestingly, 
graphene fabrication was found comparatively less expensive than the inorganic perovskite materials and the organic conducting polymers. Moreover, the tuneability and external quantum efficiency of graphene-based energy producing device starkly juxtaposed with nonmetallic and other metallic nanomaterials.
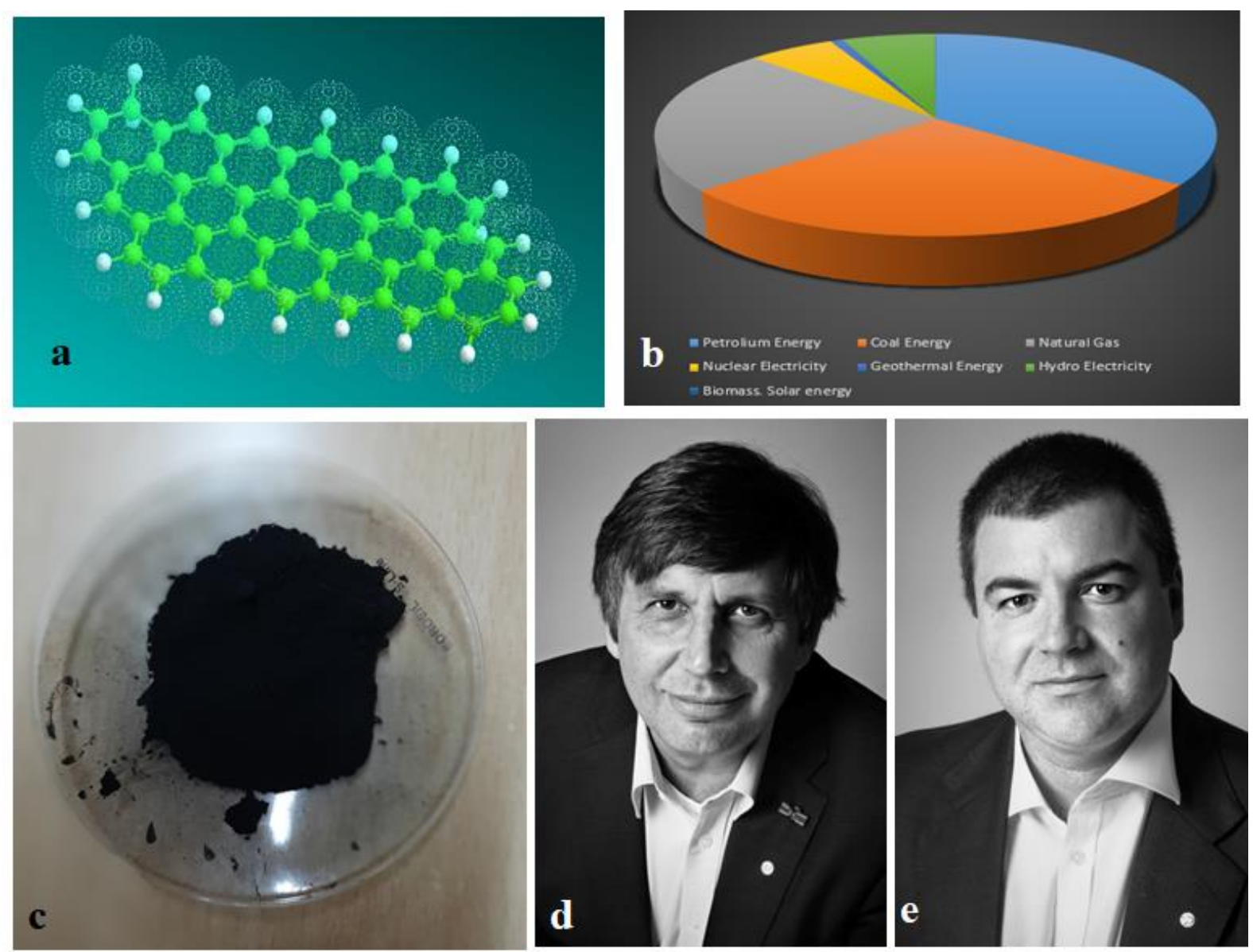

Figure 2. (a) Schematic illustration of atomistic single-layer graphene;(b) Pie chart of global energy consumption of the year 2017; Illustrated photograph of (c) Graphene powder (d) Andre Geim and (e) Kostya

Novoselov. Reproduced with permission. Copyright 2019, (CNobel Media. Photo: U Montan.

This article comprehensively throws light upon graphene's current stage in solar cell industries and its increasing public demand. The state-of-the-art production and performance of these industrially-developed graphenes have been highlighted with minimal coverage of the underlying physics behind it as a plethora of review articles is available. Interestingly, this work brings a new dimension about graphene's fate in upcoming years and the possible developments of futuristic electronic and photovoltaic devices based on the current research on the prototypes.

\section{Large Scale Production of Graphene for Solar Panels}

Charles Fritts, the American inventor, pioneered the first commercial selenium-based solar panel. However, after a century of research, many multinational companies have secured laudable achievements in the bulk production of graphene-based solar cells. First Solar Inc., NextEra Energy, Canadian Solar, Hanwha-Q Cells, FreeVolt, IDTechEx are some of the most distinguished graphene-based solar cell manufacturers. Apart from them, Xiamen Eco-Sources Technologies Co. Ltd and Hebei Desheng Economic and Trade Co. Ltd is two emerging companies that had initiated manufacturing of graphene-based solar cells in R\&D. Since 2009, 
one of the leading Chinese solar cell manufacturer Trina Solar took a giant leap in the production of graphene panels [21].

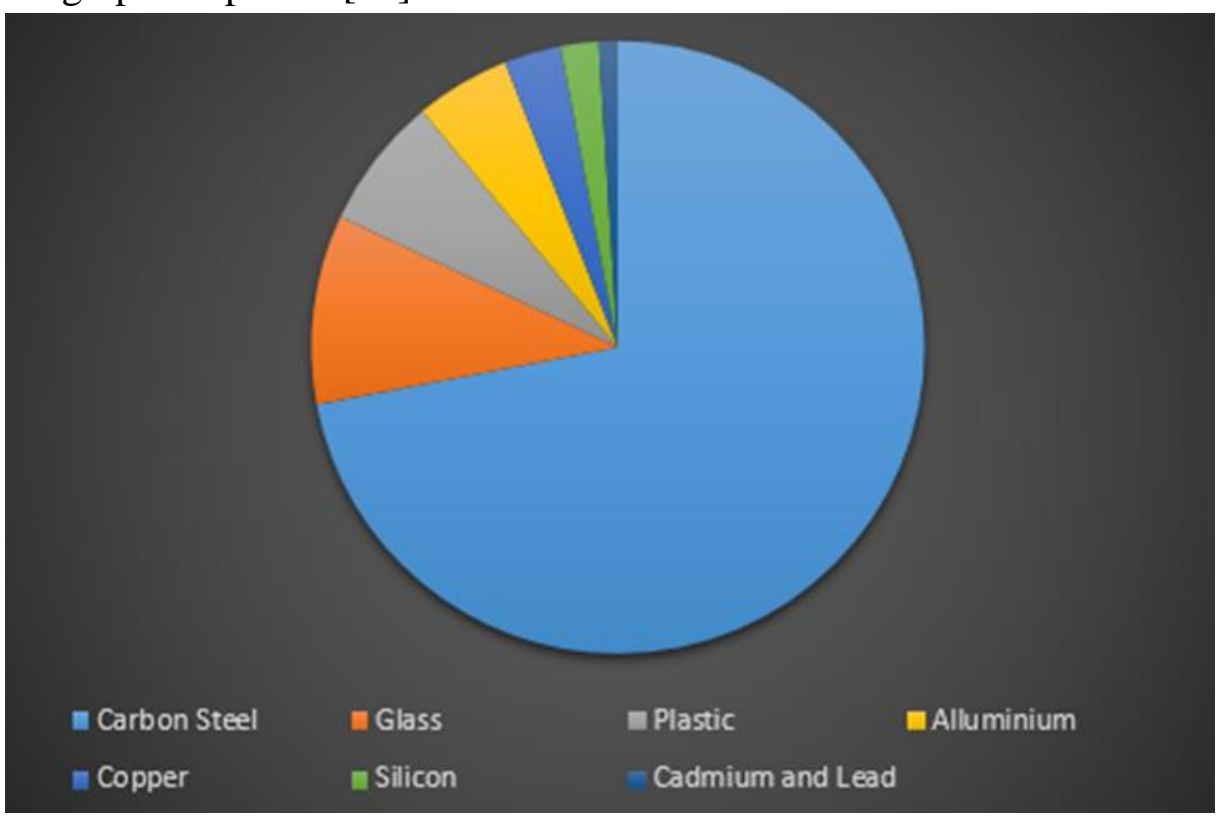

Figure 3. Pie chart for the materials required in a standard solar cell in 2018.

Similarly, the production of graphene-based panels in First Solar has thrived; otherwise, the company's level of sustainability in financial and production could never be achieved [22]. On the other hand, Canadian Solar has produced nearly $32 \mathrm{GW}$ productions which got distributed over 150 countries [23].

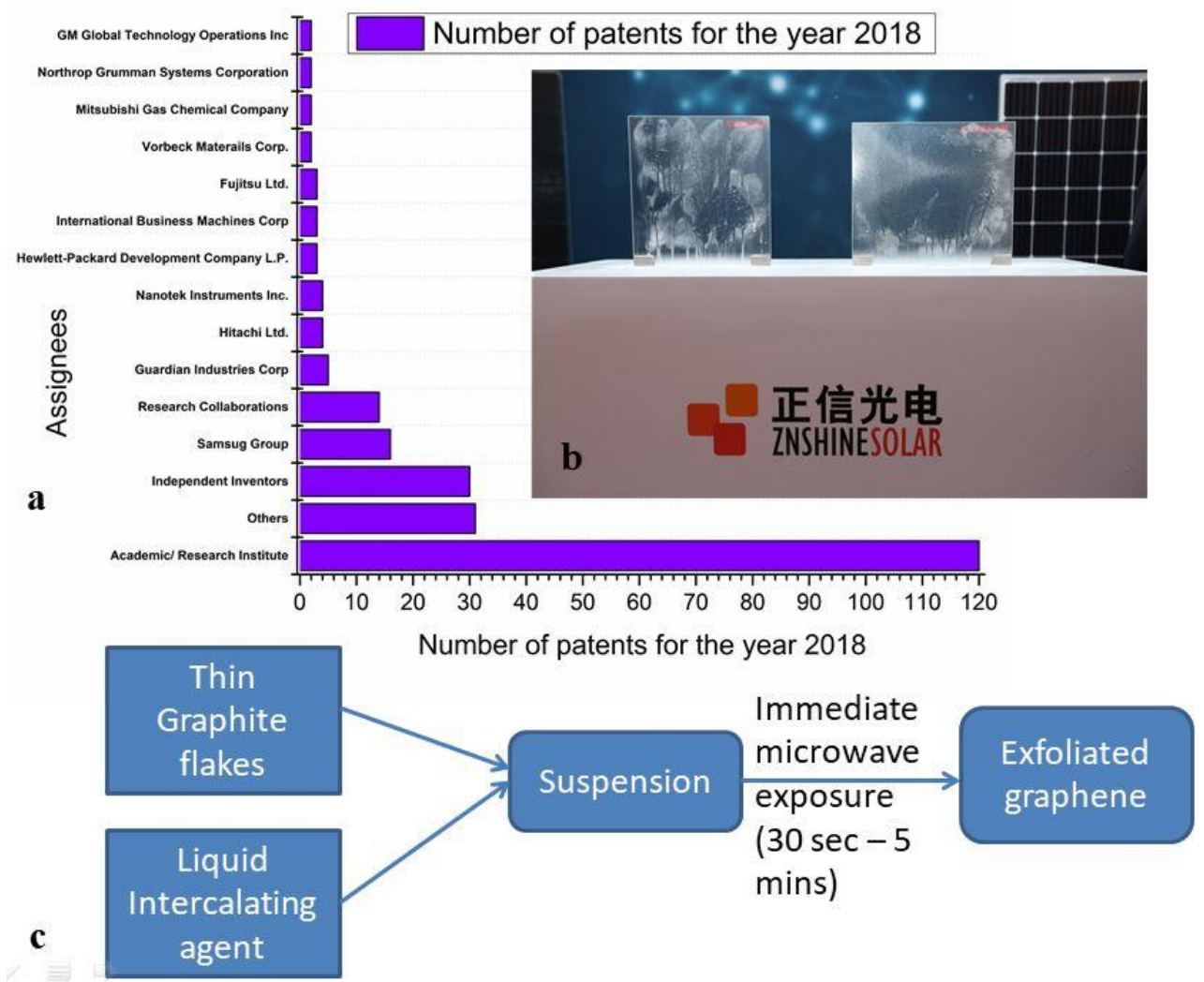

Figure 4. (a) Histogram of patents produced in 2018 by some renowned leading industrial firms; (b) Ordinary module glass (left) vs. ZNShine graphene-coated glass (right) (water sprayed under the same dust pollution, self-cleaning ability of significantly stronger graphene-coated glass) source: (PRNewsfoto / ZNShine Solar); (c) Flow diagram of graphene production in NanoXplore. 
Hence, the production of graphene progress has upscaled in these industries from the rise in financial growth as well as public demands. Hanwha Q-cells of South Korea had seen \$ 559.3 million annual sales in 2015 compared to $\$ 519$ million in 2014. In 2017, it skyrocketed to $\$ 887.5$ million, and that was evident since the company initiated the circulation of graphene panels as per customer demands [24]. The production of graphene-based solar panels is still in its infancy as other solar cell components are produced on a gargantuan scale, as displayed in Figure 3 [25]. Although, graphene-based photovoltaics have become comparatively cheaper nowadays than commercial silicon solar cells due to bulk and facile production units and surplus demand than the latter. In the international market, graphene solar cells are being sold at $\$ 0.36$ - \$ 0.42, while commercial silicon solar cells are sold at a much higher price $\sim \$ 2.58$ per panel.

NanoXplore is the largest graphene producer globally to produce high-quality graphene-enhanced polymer NanoXplore uses a one-step environment-friendly method. This giant corporate follows a unique technology to produce graphene from thin graphite flakes that are not just environment friendly but also include low-cost production and high yield, as represented in Figure 4.

On the other hand, China Carbon Graphite Group produces graphene sheets from natural graphite. From extended graphite, they also manufacture thin layers of graphene oxide via the Hummers method, which could be easily dispersed into water [26]. Liquid graphene oxide is converted into a graphene oxide sheet after deposition on Langmuir-Blodgett films. Illustrious Spanish graphene manufacturer - Graphenea uses different methodologies for graphene production. Catalyst optimization, procedure, process enhancement, and optimization of product cost are few basic things considered during graphene production. It is always keen to improve its production technology by introducing a newer version of $R \& D$ investments and scientific inventions, leading to the company's success mantra in high-scale graphene preparation [27]. In a similar trend, Saint Jean Carbon always focused on low-cost, continuous, and rapid graphene production. They mainly follow the procedure of deposition of graphene on $\mathrm{YBa}_{2} \mathrm{Cu}_{3} \mathrm{O}_{7}$ superconducting nanoparticle surfaces via matrix-assisted pulsed laser evaporation [28].

ZNShine Solar's G12 evolution era series is a popular brand in the field of graphene sheet production for solar panels. In 2018, the industry had tried to ensure the graphene sheets' quality in the G12 evolution series. It mainly consists of three types of busbar glass modules: 12-busbar, 5-busbar, and double glass graphene modules separately. To increase the light transmission process, the solar farm had introduced a graphene film layer onto it, which also had the self-cleaning capability, as represented in figure $4 \mathrm{~b}$. The R\&D section is much eager to introduce its graphene-coated modules into the market sooner. The self-cleaning property will lower the cost of cleaning the device. According to ZNShine Solar authorities, carbon coating modules help to maximize light transmission by $94.3 \%$, thus increasing overall power output by around $1 \%$. Sometimes this power output may plummet by $0.5 \%$, but it will never be lower than that [29].

The unsaturated $\mathrm{sp}^{2}$ and $\mathrm{sp}^{3}$ mixed hybridization of graphene naturally pose a unique chemical property via covalent bonding with other electron and hole contributing layers, making it more viable as an eximious multi-junction solar cell material [30, 31]. Most conventional heterojunction photovoltaics are buried inside the cell, whereas graphene has a photo-responsive 2D surface. Thus, most industries tailor this exposed surface of graphene to regulate: the polarity through doping, Fermi level (chemical potential), and optical properties 
for enhanced photovoltaic efficiency. This unprecedented nature of graphene where it can accommodate between any layer: acting as a hole transport layer as well as an active buffer layer had been shown in Figure 5.
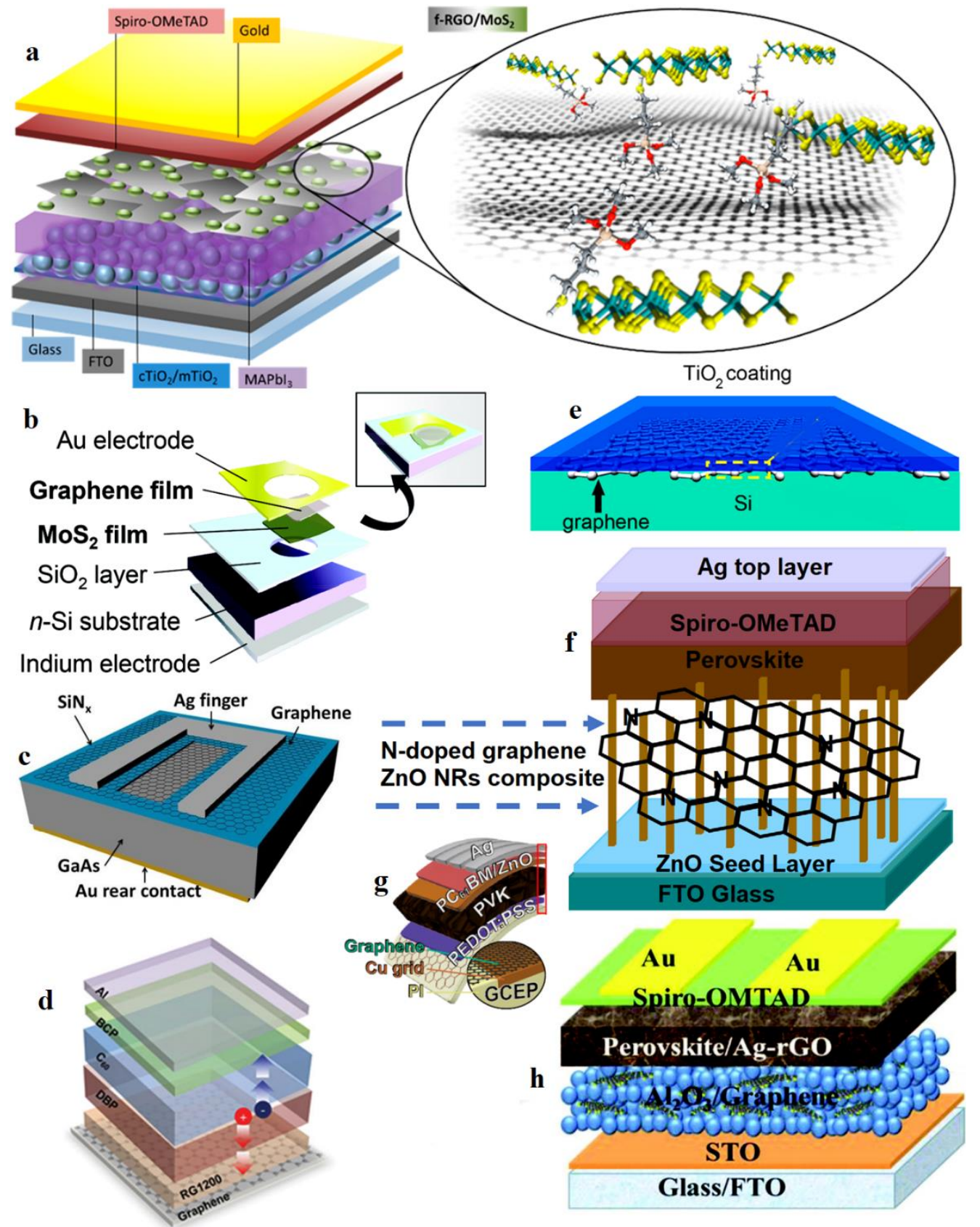

Figure 5. Schematics of graphene heterojunction photovoltaics and innovative approaches to achieve efficiency while using as HTL as well as electron transport layer; (a) Sketch of mesoscopic MAPbI ${ }_{3}$-based PSC exploiting

$\mathrm{MoS}_{2}$ Quantum Dots:functionalized-rGO hybrids as both HTL and active buffer layer [44]. Reprinted with permission from ref [44]. Copyright 2018 American Chemical Society; (b) Schematic of the graphene/MoS $/ \mathrm{n}$ -

Si solar cell [45].Reproduced with permission from ref [45]. Copyright 2015 Royal Society of Chemistry; (c)Schematic structure of the graphene/GaAs 2D solar cell. Reprinted with permission from ref [37]. Copyright 2015 Elsevier; (d) Schematic description of graphene anode organic solar cell [46]. Reprinted with permission from ref [46]. Copyright 2014 John Wiley and Sons; (e) Illustration of the $\mathrm{TiO}_{2}$-Graphene-Si solar cell structure

[47]. Adapted with permission from ref [47]. Copyright 2013 American Chemical Society; (f) Schematic illustration of PSC having an architecture of FTO/N-doped graphene- $\mathrm{ZnO}$ NR composite/ $\mathrm{CH}_{3} \mathrm{NH}_{3} \mathrm{PbI}_{3} / \mathrm{Spiro}-$ OMeTAD/Ag [48].Reprinted with permission from ref [48] Copyright 2020 Elsevier; (g) Structure of flexible perovskite solar cell PSC based on an electrode platform consisting of a Cu grid-embedded polyimide film and a graphene sheet. Reprinted with permission from ref [32]. Copyright 2020 American Chemical Society; (h) Schematic configuration of FTO/STO/mp-AG/MAPbI ${ }_{3-\mathrm{x}} \mathrm{Cl}_{\mathrm{x}}: \mathrm{Ag}-\mathrm{rGO} / \mathrm{Spiro}-\mathrm{OMeTAD} / \mathrm{Au}$. Reprinted with permission from ref [42]. Copyright 2019 John Wiley and Sons. 
High conductivity, electrolytic activities, and large surface area are some of the few other exceptional properties that make graphene-based solar panels advantageous over the first generation of photovoltaics [32-34]. Apart from the aforementioned characteristic features, the industrial approach had observed corrosion resistance ability is a phenomenal trait in graphene that stand-aloof against other hole conducting materials in a solar cell [35, 36]. Owing to these exceptional features, Li et al. reported a graphene-based multi-junction solar cell's efficiency as high as $18.5 \%$ upon combining with GaAs 2D structure [37]. After successful experimentation in $R \& D$, viable production of thin-film, tandem, and dye-sensitized graphene-based solar cells are also being manufactured commercially on a limited scale [3842]. Albeit these different types of solar cells attain whooping efficiency, but large-scale manufacturing is highly challenging to date. In 2020, a smart-designed sustainable lavish home creator $-S^{2} A$ Modular, purchased the patented rights from PV Graf ${ }^{\mathrm{TM}}$ Technology of the first graphene-based solar cell home design. Not only it cuts real-world challenges like inclement weather, dirt pollution, and rainfall but has 20 percent more efficient than any existing commercial solar panels. Also, these solar cells' production is not hampered, whereas metallic panels develop micro-cracks from high-temperature soldering [43].

Hence, from the previous reports, it is clear that graphene preparation is mostly done using thin graphite flakes by almost every graphene manufacturers and research fraternities around the globe [49-52]. Also, the extensive usage of toxic solvents like dimethylformamide (DMF) and N-methyl-2-pyrrolidone (NMP) due to the hydrophobicity of graphene makes the process less favorable. Hence, other non-aqueous solutions had been used to disperse graphite during graphene preparation. The demand for graphene oxide has also become significantly high in every graphene manufacturing firm because of its hole transport layer, minimum expense, and aqueous dispersive conditions, making it environment-friendly. Apart from these conventional ways of commercial-grade graphene productions, some alternative techniques are also being practiced to maximize graphene yield in the manufacturing unit. Over the last few years, bottom-up synthesis from non-graphitic resources could be a modern approach to replacing the graphite's micro-mechanical exfoliation process. Although these techniques had been limited to lab-scale, bulk preparation needs further optimization and modification in the industrial sector process [53-59]. At present, Rice University has developed a pulsed laserinduced graphene preparation technique on poly-imide films and other carbonaceous materials $[60,61]$. This state-of-the-art method helps obtain desired layers of graphene with high precision under ambient atmospheric conditions, and it is believed in coming years that this method can be an alternative for CVD in photovoltaic industries.

\section{Supremacy of Graphene in Solar Cell and Photovoltaics}

The fundamental manufacturing units in graphene-based solar cell companies require relatively low-cost materials where fluorine-doped tin oxide (FTO) glasses are generally used as the base material for the deposition of a graphene sheet. Industrially, this sheet is suspended over an aqueous solution, and an adhesive binder is added prior to drop-cast/painted on the FTO surface. This conventional spray-painting procedure had the advantage of controlling the thickness of the deposited layers on the glass substrate. The precise ratio of dopants, binders, conducting polymers, and other HTL materials can be engineered to attain higher efficiency than conventional Si-solar cells. Hence, every industry conceals their respective ratios in graphene panels' production to compete with their rival counterparts. 
Graphene cells primarily execute a bridging network between excited electrons and electrodes via Schottky junction [44, 62]. These excited electrons work as a suppressor of recombination holes in the solar cell, as demonstrated in Figure 6. Apart from these procedures mentioned above, the industrial approach optimizes ion concentration in solar cells by incorporating a $\mathrm{LiOH}$ electrolyte. This optimization of the solar cell enhances the efficiency further with the addition of conducting polymer.

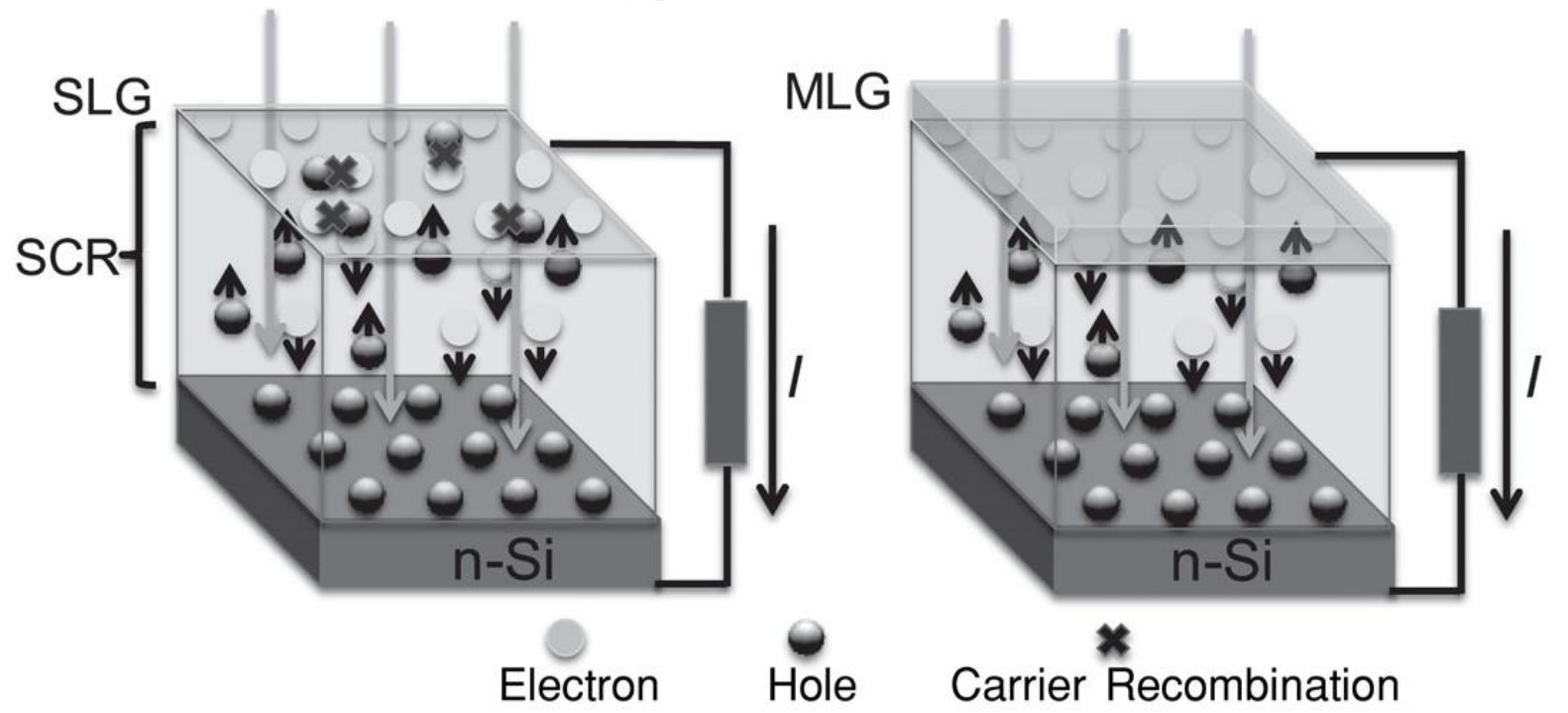

Figure 6. Schematic illustration of the separation and recombination of carriers at Schottky junctions' interfaces formed by single-layer graphene (SLG)/Si and multi-layer graphene (MLG)/Si. SCR - space charge region. Reprinted with permission ref [62]. Copyright 2013 John Wiley and Sons.

Theoretically, the bandgap value of graphene is zero as it comprises of planar monolayered structure, but the lattice defects and stacking of layers on the surface of its 2D structure increase the bandgap. A comparative bandgap pictograph of graphene with other semiconducting materials was represented in Figure 7 [63]. Apart from zero bandgap value, certain anomalous characteristics features like high electron mobility, strange quantum Hall effect, and metallic behavior in certain cases had been observed [64]. The reduction of dimension between the graphene layers can be effective in acquiring desired band gap, and therefore, the production of graphene with semiconducting property can be made possible by tuning the bandwidth $\sim 1-2 \mathrm{~nm}$.

HOMO-LUMO energy diagrams are crucial to grasp the underlying chemical interactions between graphene and other layers stacked in multi-junction and dye-sensitized solar cells. The analysis of Frontier Molecular Orbital (FMO) is one of the most important portions to know the HOMO-LUMO energy explanation outcome of graphene whether it will act as a hole generating layer or electron-donating layer. The highest and third-highest occupied molecular orbital (MO) is mandatory for investigating the MO behavior of graphene. Also, the analysis of the lowest and third-lowest unoccupied molecular orbital energy is inevitable. Electronic absorption spectra have proved that the highest occupied and the lowest unoccupied MO are alpha MO levels 242 and 243. The difference of energy between HOMO (242) and LUMO (243) was $-3.76 \mathrm{eV}$ and $2.59 \mathrm{eV}$, respectively [65]. The HOMO-LUMO energy gap of graphene was calculated through an isolated gas molecular calculation process and was found to be $6.34 \mathrm{eV}$. The calculated HOMO-LUMO energy gap value of graphene helped in elucidating its reactivity and chemical characteristics. Thus, it is essential to analyze the 
HOMO-LUMO energy levels of graphene so that its reactivity and solar cells' mechanism can be properly explained.

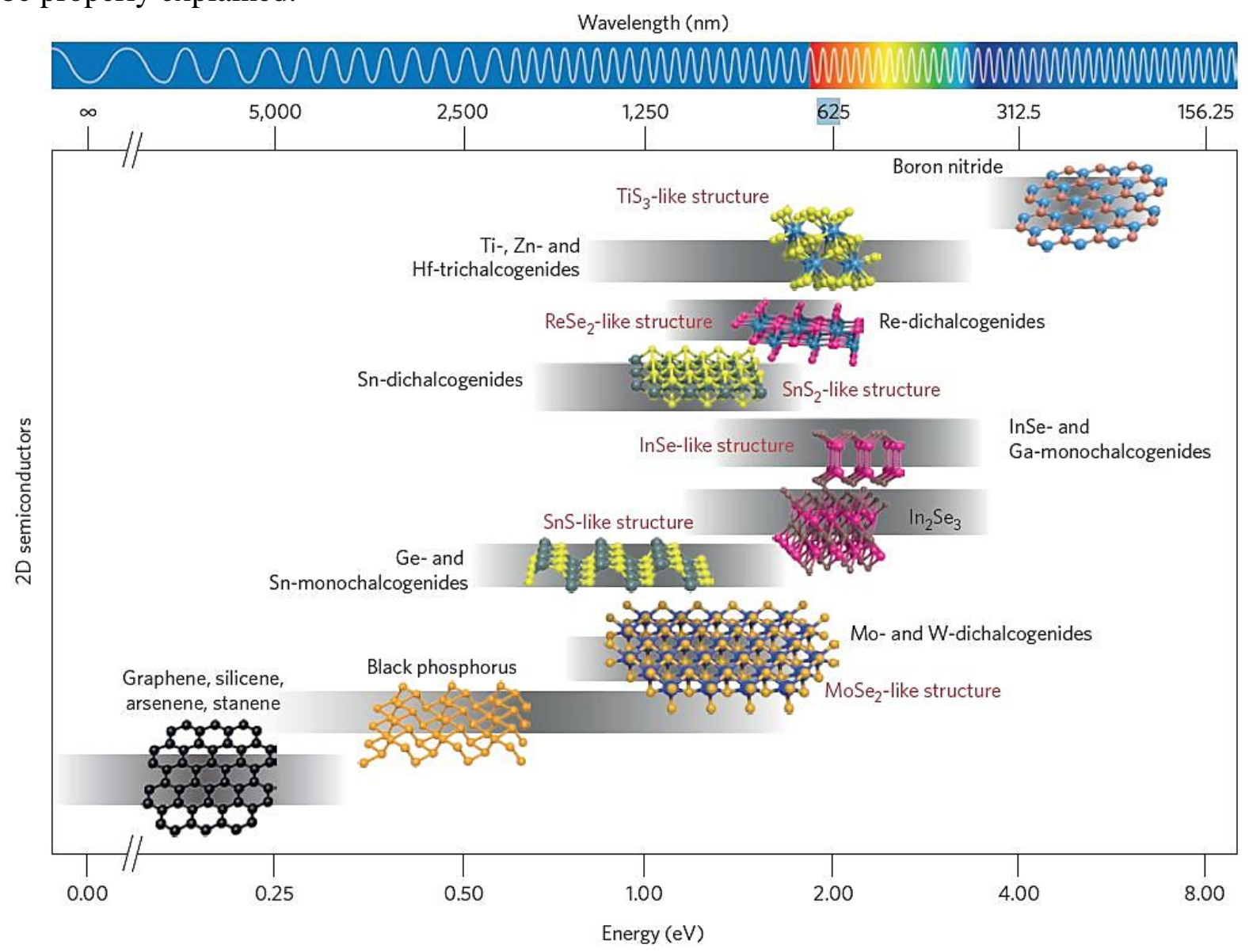

Figure 7. Comparative bandgap values for various 2D semiconductor materials investigated so far. The crystal structure is also displayed to highlight the similarities and differences between the different families. The grey horizontal bars indicate the range of bandgap values that can be spanned by changing the number of layers, straining, or alloying. This broad bandgap range spanned by all these $2 \mathrm{D}$ semiconductors can be exploited in a wide variety of photonics and optoelectronics applications, such as thermal imaging (to detect wavelengths longer than 1,200 nm), fiber optics communication (employing wavelengths in the 1,200-1,550 nm range), photovoltaics (which requires semiconductors that absorb in the 700-1,000 nm range), and displays and lightemitting diodes (requiring semiconductors that emit photons in the 390-700 nm range). Reprinted with permission from ref [63]. Copyright 2016 Springer Nature.

Despite the fact that graphene is in the youth stage of commercialization, it has been well-known for its high electrical conductivity containing both electrons and holes as charge carriers. Hence, it is also considered as zero-overlap semi-metal [66]. Generally, the carbon atom obtains six electrons, amongst which four outer shell electrons are the charge carriers in graphene. The Brillouin zone's six individual corners consist of low energy, and energy transfer linearly takes place. The Fermi level of graphene alters with doping; hence it helps to become more effective as an electronic conductor. This property makes it a promising candidate as an electrode in solar cell industries. The charge carrier density impacts immensely on the reflection and transparency property. Henceforth, graphene's high optical transparency sums up its privilege over its metallic counterparts in solar cells. Dynamic conductivity of heteroatom doped graphene reaches the universal constant value at low temperature [67]. Therefore, transparency and charge carrier density is dependent on each other as an electrode in solar cells. Thus, it can be concluded that direct inter-band transmission of electrons helps reveal graphene's optical properties. 
The mechanical strength comprising graphene's flexibility acts as an advantageous parameter in solar panels and consequently, the demand for CVD-graphene has hastened due to its flexible nature [68]. The flexibility and high mechanical strain make it more durable and reliable as an electrode material [69]. Hence, the flexible nature enables the possibility to cut the material into thinner pieces for various categories of solar cells. Fortunately, graphene is one of the lightest and strongest materials available on earth, creating high opportunities in photovoltaics industries with high longevity and facile transportation. With a background as a zero bandgap 2D material, the filling factor is another parameter that makes this wonder material a demanding substance among photovoltaics companies. As an efficiency measuring unit or factor to absorb the energy, graphene is engineered between two layers that augment the extraction ability and electron mobility due to its enhanced fill-factor [70]. In the case of graphene, the fill factor is analogous to its efficiency in fabricating anodes for solar cells and diodes. The efficiency in absorbing the pumped energy from the solar radiation will also help estimate the graphene solar cell's mechanical efficiency. From the following mathematical expression, it is possible to know the factors that influence the filling factor of a particular material i.e.

$$
1-\exp \left(-F \frac{\pi r^{2}}{S} \alpha L\right)
$$

Herein, $S=$ the cross-sectional area; $r=$ radius; $\alpha=$ absorption co-efficient; $L=$ length of the double layered fibre being used into the setup and $F=$ filling factor.

From the above expression, it is quite evident that the filling factor is significant for double-layered materials like graphene. Apart from that, the length of the fiber used in the setup will also have to be increased, and the calculation of the filling factor to obtain the efficiency helps in many ways. It minimizes the mathematical complexities of calculating absorption efficiency differently and lowers the time required to perform a complete absorption efficiency estimation. Hence, calculation of the filling factor is necessary for knowing its efficiency as an electrode of solar cells.

Similar to explaining the fill-factor equation for graphene anodes, it demonstrates the impact and importance of constructing solar cells. Reduction of the cross-sectional area of the used material would significantly reduce the amount of absorption [71]. In a similar trend, reducing the radius will increase the absorption efficiency of absorbing material - graphene. An increase in the values of $L$ and $\alpha$ will also increase the absorptive efficiency of graphene electrodes used in the solar cell. It is quite natural that the increase in both the aforementioned parameters will increase the absorbing material's absorption efficiency. Hence, before incorporating graphene as an electrode in a solar cell, it is always necessary to supervise the parameters that control the fill factor and enhance the graphene electrode's efficiency in the solar cell; otherwise, the solar cell will suffer from low efficiency and durability. Graphene demonstrated extraordinary electron mobility even at a temperature range of $10 \mathrm{~K}$ to $100 \mathrm{~K}$, and the electrons exhibited free and independent movement [72]. For this particular material, the defect scattering method was generally followed as dominant scattering. It had been found that the scattering phonons at room temperature showed a higher value than copper, which is considered an efficient electron conductor in household appliances. The acoustic phonon scattering value for graphene is nearly $2,00,000 \mathrm{~cm}^{2} \mathrm{~V}^{-1} \mathrm{~s}^{-1}$ which is nearly ten times higher than copper [73, 74].

In 2020, Balandin quoted a brief perspective that the possibility of having a diverse range of applications would rise upon exploiting graphene's phononic properties than electronic 
characteristics [75]. So far, the theoretical and experimental data strongly suggest graphene has been a superior tour-de-force material amongst all existing semiconductors. Hence, over the last decade, these wonder material's phenomenal features brought many gazes to solar cell industrialists. Thus, graphene is not confined only to lab-scale research, but graphene-based products' commercialization has gradually begun.

\section{Effects of Graphene Layers in Solar Cell}

In 2018, Wu et al. highlighted that the quenching effect goes hand in hand with solar efficiency and fill factor of graphene layers; therefore, fluorescence property needs to be demonstrated using fluorescence imaging and bio-sensing ability [76]. This design's key element mainly depended upon the designation of absorbing graphene layer with the rigidity and thickness of spacer that had already been adjusted to tune the distance between fluorophore and graphene. The quenching efficiency did not reach beyond a certain limit for a particular chemical entity, and it was observed in the case of graphene the value did not exceed $30 \%$ even when the distance between the dying material and graphene was increased up to $30 \mathrm{~nm}$. In figure 8 , the schematic nanostructure model was shown where fluorescence quenching was observed.

A

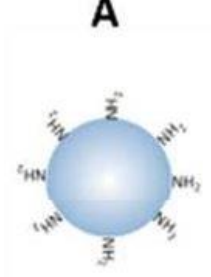

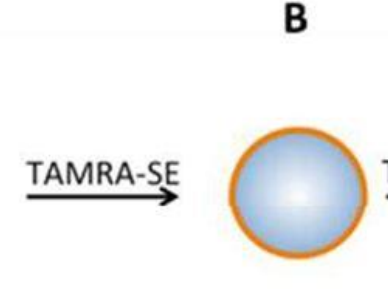
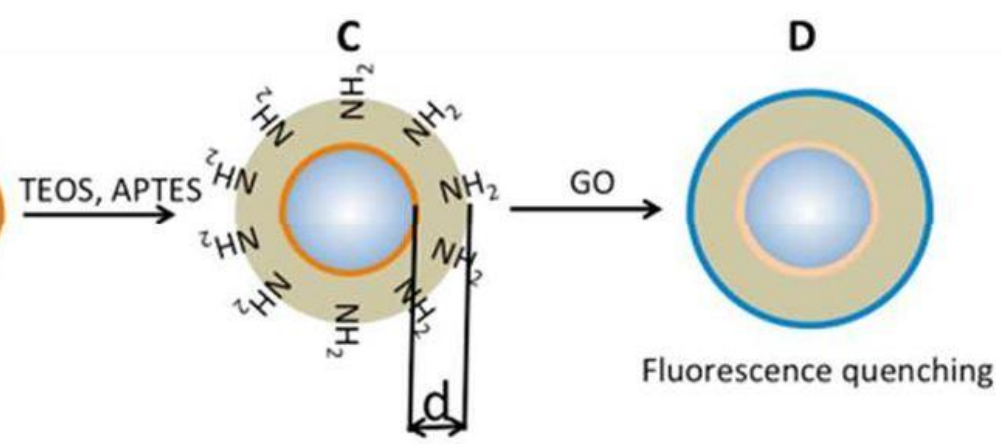

Figure 8. Schematic diagram of the synthesis of a nanostructure model (SiNPs@TAMRA@Si-NH2) for studying fluorescence quenching ability of graphene oxide (GO);(a) Amino-modified silica nanoparticle; (b) the nanoparticle was conjugated with TAMRA through succinimidyl ester;(c) A rigid silica shell with different thickness was formed to separate the fluorophore and GO;(d) GO wrapped the silica nanocomposite tightly by the strong electrostatic interaction between the second layer of amino-silica and GO. Reprinted with permission from ref [76]. Copyright 2018 American Chemical Society.

Photo-active graphene is generally produced using chemical functionalization techniques from pristine graphene, where different kinds of light-harvesting molecules are chemically attached [76-78]. It was also evident whenever chemical functionalization had been bypassed, the strong electrostatic force and $\pi-\pi$ interactions within the interlayers of pristine graphene ended up in aggregation of the layers. Hence rising photovoltaic industries prefer to GO as HTL over pristine graphene.

Apart from using mere GO electrodes, this chemical functionalization process had experimented with silver doped r-GO had also been used as an efficient electrode in various dye-sensitized solar cells (DSSC) [79, 80]. Although it boosted efficiency, large-scale production would be highly expensive due to the silver nitrate $\left(\mathrm{AgNO}_{3}\right)$ precursor. Similarly, a trace amount of gold had been doped graphene solar cell prior to usage in DSSC [81]. In contrast to Ag-doped GO films, short circuit density reduced in Au doped graphene films with increased $\mathrm{Au}$ concentration. With respect to chemical functionalization, the enhanced 
efficiency of graphene-based solar cells depended on two things: charge transfer resistance and lowest leak current.

Lately, it was also observed that Schottky solar cells were gaining much more attention due to their work efficiency. It contains the unconventional junction of the Schottky structure of graphene and silicon [82]. These graphene/silicon hybrid solar cells had undergone much advancement in the last few years. Various new technical strategies had been used to improve the efficiency and steady power conversion characteristics of the graphene/silicon solar cells. The quasi $\mathrm{p}-\mathrm{n}$ junction of this graphene/silicon solar cell gets tunneled by $\mathrm{Al}_{2} \mathrm{O}_{3}$ interlayers between silicon and graphene. This technology increased the PCE value up to $8.5 \%$ without any doping in the graphene layers. These high-efficiency cells have been more desiring for the current needs, and gradually, market demands are rising too. Hence, graphene/silicon doped solar cell industrial production is progressing simultaneously with mere graphene solar panels. Similarly, with the growth of graphene quantum dots (GQDs), three different types of graphene quantum dot solar cells viz. N-doped GQDs (NGQD) [83] and S-doped GQDs (SGQD) [84] and S-N co-doped GQDs (SNGQD) [85] emerged out that are mainly produced by using hydrothermal methods. Among these aforementioned GQDs, the S, N- co-doped GQDs were mostly efficient because they made the open-circuit voltage rise up to $360 \mathrm{mV}$, short circuit current by $1.84 \mathrm{~mA} \mathrm{~cm}^{-2}$, and power conversion efficiency up to $0.293 \%$. However, these cells aren't suitable for household purposes but would be a boon for small electronic appliances in the future. Hence, the future usage of these eco-friendly GQD solar cells is indeed bright as these cells are quite transparent and can be used in window pane in the future. Apart from its low production cost and reliability, it also assures less or zero pollution for a sustainable environment that caused more and more advancement and studies in this field.

\section{The Present Inside Story of Graphene-Based Solar Cell}

In the recent past, it has been found that graphene-based solar cells are quite prosperous in the field of renewable energy production over conventional silicon-based solar panels, which have a detrimental environmental impact upon discarding. A team of researchers from MIT brought the future one step closer with the fabrication of low-cost, eco-friendly transparent graphene solar cells and harnessed a substantial amount of energy [86]. Ubiquitously, various private companies have taken initiatives to produce only graphene-based solar cell products ever since it is widely accepted in the global market. The primary initiative in this regard is an economically viable setup, and graphene electrodes used in the cells are made of inexpensive and most abundant carbon resources. On the other hand, carbonaceous precursors used to manufacture photovoltaics are easier to manufacture, making the entire device and setup light weight and portable. These are the few gorgonized changes administered into the setup of solar panels by various companies for an economical and environment-friendly design. German industry - Aixtron manufactured a large area deposition of graphene using a roll-to-roll system under ambient conditions. This technology might be a game-changer as bulk scale CVD processes do not require CVD process and inert conditions [87]. In this regard, the light transmission performance in the G12 evolution series of ZNShine Solar had been increased by introducing thin graphene film in the setup. The company had also collaborated with Bharat Heavy Electricals Limited for shipment of $10 \%$ of graphene-based photovoltaics [29, 88]

Other than this, Shanghai-based manufacturer - China Carbon Graphite Group distributes raw products of the graphene-based solar cell through its subsidiary wing - Royal 
Elite New Energy Science and Technology [89]. This company's major products are graphene bipolar plates, graphene electrodes, and GO for constructing solar panels. Canadian graphite manufacturer - Elcora Advanced Material produces few-layered graphene without depending on non-functionalized chemical moieties and acid [90]. Their products are innovative and unique in their own way since operating a large-scale batch reactor monitoring eco-friendly green processes and cost-effectiveness is extremely challenging. As the rush for a sustainable future is high, companies like First Graphene and Grafoid Inc. invested huge capital resources to develop low-cost graphene nanoplatelets using environment-friendly routes [91, 92]. First, graphene is trying to produce high-quality pristine graphene nanoplatelets using electrochemical exfoliation from natural graphite ore that can be used as an efficient graphene electrode in graphene-based solar cells. On the other hand, Grafoid's products are prepared at room temperature, and so far, mineral acids had been avoided in manufacturing bulk amounts. Grafoid had collaborated with Focus Graphite Group, and they own 40\% of the company's share. This kind of developmental strategy helped it increase its $\$ 3.5$ million aids from private investors in 2013 to $\$ 6.46$ million USD grant from the Canadian government. Production of graphene electrodes had been an inevitable part of graphene solar panels hence, Canadian manufacturer - Saint Jean Carbon had pioneered in fabricating graphene anodes as well as focused on producing graphene-induced lithium-ion batteries [93].

British start-ups Graphene NanoChem and Haydale Graphene Indus are eyeing on design and delivering graphene-based applications for global consumers [94, 95]. Haydale's products are popular for their magnificent quality as well as they started producing flexible graphene electronics and conductive graphene ink. The company is trying to capture the global market by investing $\$ 7.8$ million in improving the efficiency and performance of its products. Processing and handling the nanoplatelets is the prime strategy of the R\&D wing of this company. This strategy prompted Briggs Automotive Company to partner with Haydale and manufacture the first super-car Mono-R of the future with a graphene carbon fiber composite body. The main reason for researching this topic is getting information on whether it can be used to make energy storage devices, photovoltaic, and sensors. Not only industries, UK space agency and the University of Central Lancashire has partly funded the start-up industry to exploit graphene in an outer-space environment at the cryogenic condition as a sensor. On the other hand, Graphene NanoChem produces superior quality few-layered graphene from bottom-up chemical synthesis. Likewise, certain small-scale industries like XG Sciences have patented cutting-edge technology to produce graphene in various forms suitable for target applications [96, 97]. Most of these innovations have many speculations as conductive inks in electronics and photovoltaics. Hence once again, it proved the variation in the shape and morphology of graphene varies its application. Versarien has recently launched a grapheneenhanced photothermal protective mask in the fight against the dreaded SARS-CoV-2 responsible for huge fatality in this pandemic of 2020 [98]. Freshly, it has signed a partnership with a US-based carbon nanotube manufacturing company, giving it the chance to examine its performance and efficiency as a part of graphene-based solar cells. To capture the market demands, the industry has also collaborated with NovoCarbon Corporation to innovate inexpensive ways of producing pristine graphene films. Previously, the company was known to engineer energy storage devices and inks based on graphene nanoplatelets [99]. Russian industry - AkKo Lab has modified Li-ion secondary batteries with $5 \mathrm{~nm}$ graphene anodes [100]. The energy storage device is still in the prototype stage and is considered the next 
generation highly intense energy storage device for solar cells. Over the years, the company had been selling graphene, GO, and nano-graphite as chief products.

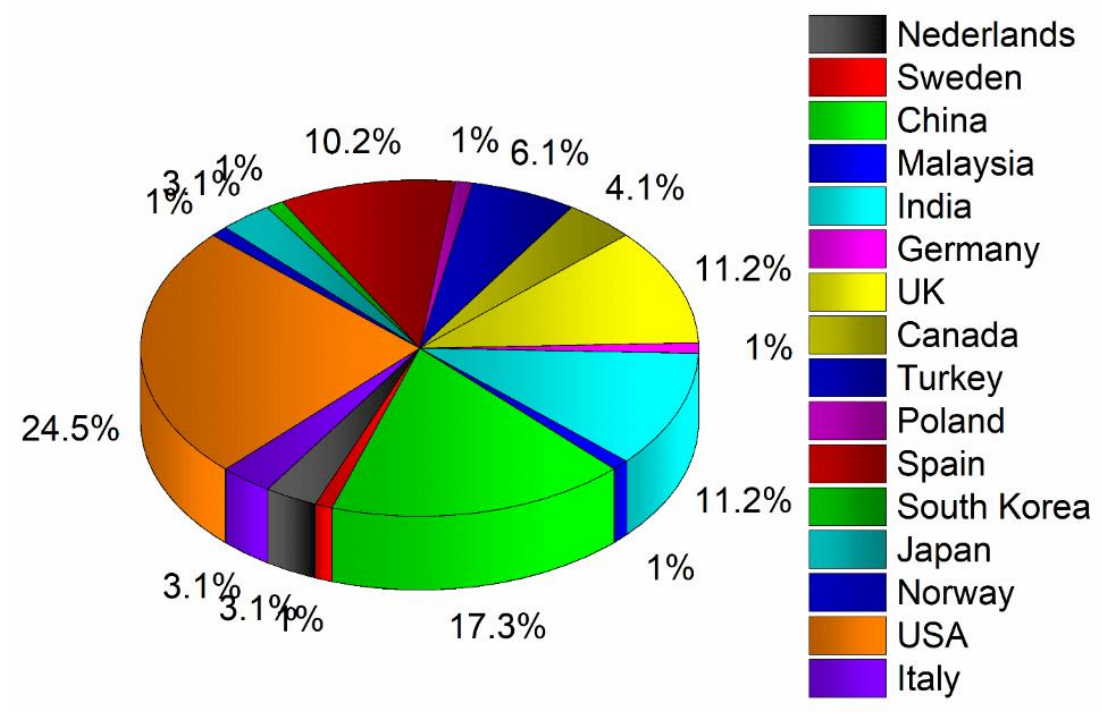

Figure 9. Pie chart of worldwide graphene manufacturing.

Fourteen tonnes were produced in 2009, after a decade, graphene production skyrocketed to 1200 tonnes and is expected to reach over 1500 tonnes by the end of 2020 [101]. This statistic highlighted the gradual rise of graphene over the years due to multiple commercial products that are available in the market apart from solar panels. According to US Geological survey in 2019, China, India, Brazil, Canada, and Mozambique are the top graphite mining nations globally. This census corroborates the significant rise of graphene panel manufacturing in China and Canada over the last couple of years. The nation-wise pie-chart analysis of graphene manufacture in figure 9 shed light on the increasing extent of graphene production in the global market. From the worldwide graphene manufacturing data, it has been made clear that the US is the highest producer of graphene-based solar cell in the world with a total of $24 \%$ of global manufacture preceded by China (17\%), India (11\%), the UK (11\%) and Spain (10\%) [102].

At present, the high cyclability and rate capability had given graphene a phenomenal status as an electrode for solar cells, and statistics of graphene production had risen significantly. Not only has it been a hot topic for the photovoltaics industry, but various renowned tech-giants and multinational companies had also launched graphene-based products for global customers, as displayed in Table 1. Several graphene properties had been utilized, and hence it had been made possible that this wonder-material can be a part of earphone as a bass treble enhancer, strengthening a bicycle frame and a chief component for a luxurious super-car-like Lamborghini. To make more gradation in graphene products, every multinational company is bringing out their best to improve research and development. It is not like all $\mathrm{R} \& \mathrm{D}$ techniques and strategies used by these numerous companies are always generating fecund results. Sometimes, it had also caused countless shortcomings and failures. Although many research articles are published every year by academicians, most of them fail to address the industrial needs. Thus, research on graphene production is confined within lab walls. Almost 16 years had passed since the discovery of graphene, but it is being recognized outside the research fraternities very late due to a lack of 'lab-to-land' implementation research. However, the link between industry and academic institutes is bridged recently by commercializing certain graphene-based products apart from photovoltaics. 
Table 1. List of various commercially available graphene-based commodities

\begin{tabular}{|c|c|c|c|c|c|}
\hline Company & Model & $\begin{array}{c}\text { Country } \\
\text { Origin }\end{array}$ & $\begin{array}{l}\text { Properties } \\
\text { Utilized }\end{array}$ & Features & Ref \\
\hline MediaDevil & $\begin{array}{l}\text { Artisanphonics CB- } \\
01 \text { earphones }\end{array}$ & UK & Acoustic & $\begin{array}{l}\text { Few layers of graphene } \\
\text { allowed to improve both } \\
\text { the low-end (bass) and } \\
\text { the high-end (treble) of } \\
\text { the audio-wave } \\
\text { earphones }\end{array}$ & [103] \\
\hline McLaren & $\begin{array}{l}\text { RM 50-03 } \\
\text { Tourbillon Split } \\
\text { watch }\end{array}$ & UK & Stiffness & $\begin{array}{l}\text { Graphene makes the } \\
\text { product world's lightest } \\
\text { watch }\end{array}$ & {$[104]$} \\
\hline Nanomed & $\begin{array}{c}\text { Agile R100 } \\
\text { biosensor }\end{array}$ & USA & Electro-chemical & $\begin{array}{l}\text { Surface of graphene } \\
\text { enables direct binding of } \\
\text { proteins and reduce non- } \\
\text { specific bindings in } \\
\text { cancer cell detection }\end{array}$ & [105] \\
\hline Catlike & $\begin{array}{l}\text { Catlike Mixino } \\
\text { helmet }\end{array}$ & Spain & Mechanical & $\begin{array}{l}\text { Graphene nanofibers } \\
\text { inner skeleton of the } \\
\text { helmet makes it super- } \\
\text { light }\end{array}$ & {$[106]$} \\
\hline Vittoria & Graphene 2.0 tyres & Italy & Mechanical & $\begin{array}{l}\text { Incorporating graphene } \\
\text { in tires make it puncture } \\
\text { resistant, boost its speed, } \\
\text { performance and } \\
\text { durability }\end{array}$ & [107] \\
\hline Colmar & $\begin{array}{l}\text { Graphene Plus G+ } \\
\text { apparels }\end{array}$ & Italy & $\begin{array}{l}\text { Thermoregulation } \\
\text { technology, } \\
\text { electrical and } \\
\text { antibacterial } \\
\text { property }\end{array}$ & $\begin{array}{l}\text { Graphene in clothing } \\
\text { preserves the body in } \\
\text { cold weather and } \\
\text { eliminates heat in a hot } \\
\text { climate. Anti-static } \\
\text { fabric avoiding } \\
\text { proliferation of bacteria }\end{array}$ & {$[108]$} \\
\hline $\begin{array}{c}\text { Indian } \\
\text { Motorcycle }\end{array}$ & $\begin{array}{l}\text { Clima Command } \\
\text { Classic Seat }\end{array}$ & USA & Thermal & $\begin{array}{l}\text { Graphene ensures heat } \\
\text { control and flexible seat } \\
\text { cover for automobiles }\end{array}$ & [109] \\
\hline CalBattery & $\begin{array}{l}\text { SiGr Anode for Li- } \\
\text { ion battery }\end{array}$ & USA & Chemical & $\begin{array}{l}\text { Composite of silicon- } \\
\text { graphene as anode }\end{array}$ & {$[110]$} \\
\hline Hella & $\begin{array}{c}\text { Graphene engine oil } \\
\text { additive }\end{array}$ & Germany & Tribological & $\begin{array}{l}\text { Graphene nanoplatelet } \\
\text { added to reduce wear } \\
\text { and friction in IC } \\
\text { engines }\end{array}$ & [111] \\
\hline Emberion & $\begin{array}{l}\text { VIS-SWIR linear } \\
\text { array graphene } \\
\text { photodetectors }\end{array}$ & Finland & Optical & $\begin{array}{lcr}\text { Graphene } & \text { helps } & \text { in } \\
\text { converting } & \text { light to } \\
\text { electrical } & \text { signal with } \\
\text { noise } & \text { reduction } \\
\text { technology } & & \\
\end{array}$ & {$[112]$} \\
\hline NanoCase & $\begin{array}{l}\text { NanoGtech phone- } \\
\text { case }\end{array}$ & Switzerland & Thermal & $\begin{array}{l}\text { Extends battery life of } \\
\text { mobile, keeping it cool } \\
\text { and regulates over- } \\
\text { heating }\end{array}$ & [113] \\
\hline $\begin{array}{c}\text { Anker } \\
\text { Technologies }\end{array}$ & $\begin{array}{l}\text { Zolo Liberty } \\
\text { headphones }\end{array}$ & China & Mechanical & $\begin{array}{l}\text { Pioneered enhanced } \\
\text { audio technology with } \\
\text { high treble due to } \\
\text { graphene }\end{array}$ & [114] \\
\hline Xiaomi & $\begin{array}{l}\text { MI Pro 3-driver } \\
\text { graphene earphones }\end{array}$ & China & Acoustic & $\begin{array}{l}\text { Graphene diaphragm } \\
\text { improves the sound } \\
\text { quality and dissipates } \\
\text { noise }\end{array}$ & {$[115]$} \\
\hline Huawei & $\begin{array}{l}\text { Mate } 20 \mathrm{X} \text { and } \\
\text { Honor } 10 \mathrm{X} \\
\text { smartphones }\end{array}$ & China & Thermal & $\begin{array}{l}\text { Graphene film act as a } \\
\text { heat sink for the cell }\end{array}$ & {$[116]$} \\
\hline FiiO & $\begin{array}{l}\text { FiiO F3 wired } \\
\text { earphones }\end{array}$ & China & $\begin{array}{l}\text { Acoustic and } \\
\text { Electrical }\end{array}$ & $\begin{array}{l}\text { Graphene diaphragm } \\
\text { high-fidelity audio and } \\
\text { excellent conductivity }\end{array}$ & [117] \\
\hline Galapad & Galapad Settler & China & Chemical & $\begin{array}{l}\text { Graphene prevents } \\
\text { moisture and acts as an } \\
\text { anti-corrosive agent }\end{array}$ & [118] \\
\hline
\end{tabular}




\begin{tabular}{|c|c|c|c|c|c|}
\hline Company & Model & $\begin{array}{c}\text { Country } \\
\text { Origin }\end{array}$ & $\begin{array}{c}\text { Properties } \\
\text { Utilized }\end{array}$ & Features & Ref \\
\hline Graphene Tech & $\begin{array}{l}\text { GP500 graphene } \\
\text { nanoplatelet } \\
\text { extrusion polymer }\end{array}$ & Spain & Chemical & $\begin{array}{l}\text { 4-7 layer of graphene } \\
\text { dispersed in nylon- } 66 \text { to } \\
\text { make reinforced } \\
\text { polymer coatings }\end{array}$ & [119] \\
\hline TeamGroup & $\begin{array}{c}\text { Cardea Zero Z340 } \\
\text { M.2 PCIe Solid } \\
\text { State Drive } \\
\end{array}$ & Taiwan & Thermal & $\begin{array}{l}\text { Use of graphene helps in } \\
\text { cooling down the hard } \\
\text { drive }\end{array}$ & [120] \\
\hline Absolute Black & GRAPHENlube & UK & Chemical & $\begin{array}{l}\text { Claimed as world's } \\
\text { longest-lasting lubricant } \\
\text { for a cycle chain }\end{array}$ & [121] \\
\hline Dassi & Interceptor cycle & UK & Mechanical & $\begin{array}{l}\text { Graphene infused in } \\
\text { framework makes the } \\
\text { cycle extreme light and } \\
\text { hardy }\end{array}$ & [122] \\
\hline M-Solv/Thales & Graphene supercap & $\begin{array}{l}\text { UK and } \\
\text { European } \\
\text { Union } \\
\end{array}$ & Electrical & $\begin{array}{lr}\text { World's } & \text { first } \\
\text { commercial graphene } \\
\text { supercapacitor }\end{array}$ & [123] \\
\hline Graphenea & $\begin{array}{l}\text { GFET S-20 sensor } \\
\text { chip }\end{array}$ & Spain & Electro-chemical & $\begin{array}{lr}\text { Current } & \text { leakage } \\
\text { detection is possible } \\
\text { even in liquid medium } \\
\begin{array}{l}\text { using } \\
\text { electrode }\end{array} \\
\end{array}$ & [27] \\
\hline First Graphene & $\begin{array}{l}\text { Pure Graph } \\
\text { elastomer }\end{array}$ & Australia & Chemical & $\begin{array}{l}\text { Graphene nanoplatelets } \\
\text { had been used to } \\
\text { increase abrasion } \\
\text { resistance and strength } \\
\text { in this product }\end{array}$ & [91] \\
\hline Head & $\begin{array}{l}\text { Graphene XT tennis } \\
\text { racquet }\end{array}$ & $\begin{array}{c}\text { USA- } \\
\text { Nederland }\end{array}$ & Mechanical & $\begin{array}{l}\text { Graphene re-distributes } \\
\text { the weight making it } \\
\text { lighter with increased } \\
\text { swing weight and } \\
\text { maneuverability }\end{array}$ & [124] \\
\hline Biolin Scientific & Q-Sense GO Sensor & Sweden & Electro-chemical & $\begin{array}{l}\text { With the help of GO the } \\
\text { device can measure the } \\
\text { quantified amount of } \\
\text { DNA, proteins, bacteria } \\
\text { and viruses }\end{array}$ & [125] \\
\hline Grays & $\begin{array}{l}\text { GR Composite } \\
\text { hockey sticks }\end{array}$ & UK & $\begin{array}{l}\text { Stress and } \\
\text { Chemical }\end{array}$ & $\begin{array}{l}\text { Graphene composite } \\
\text { makes the hockey sticks } \\
\text { light and exceptionally } \\
\text { strong }\end{array}$ & [126] \\
\hline $\begin{array}{l}\text { Applied } \\
\text { Graphene } \\
\text { Materials }\end{array}$ & $\begin{array}{c}\text { Genable } 1000 \text { series } \\
\text { epoxy resin }\end{array}$ & UK & Chemical & $\begin{array}{l}\text { Used in paints and } \\
\text { coating with the addition } \\
\text { of graphene makes it } \\
\text { anti-corrosive }\end{array}$ & [127] \\
\hline Iterchimica Srl & Gipave asphalt & Italy & $\begin{array}{l}\text { Thermal and } \\
\text { Mechanical }\end{array}$ & $\begin{array}{l}\text { Graphene enhanced } \\
\text { polymer gives long- } \\
\text { lasting asphalt for road } \\
\text { making }\end{array}$ & [128] \\
\hline Momo Design & $\begin{array}{l}\text { FGTR Graphene } 1.0 \\
\text { helmet }\end{array}$ & Italy & $\begin{array}{l}\text { Mechanical and } \\
\text { Thermal }\end{array}$ & $\begin{array}{l}\text { Heat dissipation and } \\
\text { graphene distributes the } \\
\text { force of impact on } \\
\text { accident }\end{array}$ & [129] \\
\hline NRC & Everest sunglass & Italy & Optical & $\begin{array}{l}\text { Graphene increases the } \\
\text { flexibility, lightness and } \\
\text { durability of the frame }\end{array}$ & [130] \\
\hline inov-8 & G-series shoes & UK & Mechanical & $\begin{array}{l}\text { First-ever sports shoes } \\
\text { with graphene and } \\
\text { considered to have the } \\
\text { toughest grip }\end{array}$ & [131] \\
\hline Fadel & $\begin{array}{c}\text { Freshoes (prototype } \\
\text { stage) }\end{array}$ & Italy & $\begin{array}{l}\text { Thermal and } \\
\text { Antibacterial }\end{array}$ & $\begin{array}{l}\text { Futuristic footwear } \\
\text { controlling freshness } \\
\text { and heat flow of body } \\
\text { and environment due to } \\
\text { graphene }\end{array}$ & [132] \\
\hline Lamborghini & $\begin{array}{l}\text { Terzo Millenio } \\
\text { electric super-car } \\
\text { (prototype stage) }\end{array}$ & Italy & Electrical & $\begin{array}{l}\text { Future electrical super- } \\
\text { car collaborated with } \\
\text { MIT in prototype stage }\end{array}$ & [133] \\
\hline
\end{tabular}




\section{The Limitations in Brief}

Over a decade of dedicated research and meticulous scientific findings, graphene has established itself as an excellent solar cell material that will be efficient, inexpensive, and environmentally benign. Numerous research contributions by graphene manufacturing private sectors and academic institutes had developed procedures and techniques to get more efficient and active graphene panels. In contrast to various advantages as a part of solar cell, it also possesses some limitations that can also become a barrier from considering its status as one of the best materials for an efficient solar cell. Graphene is generally considered a brilliant conductor of electricity, but it does not possess any band gap in its molecular orbital structure and that shortcoming in its molecular structure is being rectified by researchers over the last few years [134]. Once this limitation gets rectified, it can be used as a highly efficient anode in almost every solar cell type. Moreover, graphene inclines to get oxidized in any oxidative environment. Thus it causes structural changes and further leads to alteration of its chemical properties. The unique characteristics for which it has gained a universal symbol as a wonder material might get tarnished in a nutshell. This kind of chemical alteration and structural change can be an obstacle whenever a large amount of energy production is considered. Other than these two limitations, graphene also exhibits some toxic characteristics. That is another problem in the development stage to be eliminated by the research communities. Hence, these are the few drawbacks that are causing barriers in usage and approval of graphene in the solar cell for broad-scale commercialization.

Several steps are being taken to address these limitations above by industries and academic institutions. Usually, two electrodes are used in secondary cells, but only one electrode is used in the case of solar cells. Hence, the change in work function value and direction of electron flow is the main two things that need to get addressed. In a solar cell with only one electrode, the whole system is complex for electrons' flow. To retain the whole process intact, investigators had tried to change the work function, but it is a highly challenging task to change the work function of a certain material. Apart from this persisting issue, it had been found that depositing graphene electrodes into the solar setup is an arduous task. The bottom of a graphene electrode is deposited on a substrate material (generally glass or elastomers) by which the solar cell is constructed [135]. During this deposition process, water is used as a solvent as graphene tends to disperse poorly. However, to get a high degree of dispersion, various organic solvents are in trial to replace water.

Usually, in common graphene-induced solar cells, it shows a power conversion efficiency of $8.6 \%$ while embedded in the n-Si Schottky junction solar cell with AM 1.5 illumination. This value can be increased by the factor of 4.5 upon doping into solar cell material. In order to gain this, graphene undergoes doping with ionic liquids such as bis(trifluoromethanesulfonyl)amide, bistriflimide, etc. [136-138]. The shift in chemical potential due to doping helps increase the carrier density of graphene, eventually increasing the in-built potential of solar cells that help retain longer cell life than the conventional ones.

\section{The Future is Not Far}

The serendipitous discovery of graphene opened a new chapter about 2D materials with exclusive physical and chemical properties that completely contradict other existing nanomaterials. The domain of its application has already been countless and this wondermaterial is even being used as a commercial product in the fight against the pandemic of 2020 . 
The future prospects of graphene are expected to reach fathoms in upcoming years as it will not only be restricted within photovoltaics industries. Today's vast cutting-edge prototypes and experiments draw a pristine vista about graphene's fate as various entrepreneurs found its charm as a sustainable material in solving complex public demands. ISE Fraunhofer, one of the most distinguished German photovoltaic institutes, aims to use natural resources to secure the livelihood of the present and assures that future generations do not suffer from the scarcity of natural resource energy depletion [139]. To achieve this goal, the institute is prioritizing itsR\&D activity to achieve sustainability and security in the renewable energy sector. This research institute's mission is to carry out effective research works in the field of renewable energy while collaborating with a global corporation with similar interests. ISE Fraunhofer officials believe that successful research outcomes with global partners' collaboration will help achieve their organizational goal. Similarly, Tesla, another market giant in solar cell production, has set a mission to hasten the world's transition towards renewable and sustainable energy [140]. It also advocates the transition towards clean energy and changes the common people's energy usage tendency, making them more reliant on renewable energy. Conventional knowledge conveys that less reliance on fossil fuel will automatically lower the emission level into the environment. In order to facilitate this cause, Tesla is giving importance to the procedures of new-age energy production, storage, and consumption for the consumers. Powerwall, Powerpack, and Solar-roof are the three main energy solutions invented by Tesla to retain their mission and to achieve their organizational goal. Some of these energy solutions are directly linked with the usage of graphene derivatives for future prospects. Not only the usage of graphene has been restricted within this planet, but the Breakthrough Starshot project aimed to develop graphene for the interstellar voyage in spacecraft-related works [141]. The project was a vision of the late Stephen Hawking, Mark Zuckerberg, and Yuri Milner to develop ultrafast photon-driven nano-crafts into the Alpha Century star system. Graphene has been considered a core material to make these hi-tech nano-crafts reach this stellar system within the next twenty years for its light weightiness and photovoltaic capability. Similarly, graphene-enhanced supercapacitors have a unique property to get charged and discharged within a short span, making them suitable for spacecraft. Aerospace business giant Thales is trying to utilize graphene's unique characteristics in aerospace technology, and research work has been commissioned for an extensive five years from 2019 [123, 142].

Graphene has proved to be one of the most successful materials in diverse terrestrial electronics, and it is considered to be equally efficient in designing spacecraft to sustain a hostile environment of outer space. This lightweight material helps retain the spacecraft's low mass and the solar panels in satellites due to their corrosion resistive property and photovoltaic performance. These properties will make the spacecraft capable of obtaining high-speed acceleration for a long duration and generating electricity from the sun, and thus prototype experiment was undergone by Boreal Space in the stratosphere [143].

It will also help the spaceship endure the low temperature of space due to its inert nature and high chemical stability at cryogenic conditions. Therefore, graphene-made space voyagers and crewless vehicles will also be tailor-made for Martian atmosphere and terrain that contains only $1.3 \%$ of oxygen, and the average temperature is also much lower than the earth, i.e., $60^{\circ}$ C [144-146]. Hence, graphene-made space craft will easily endure low oxygen and sub-zero temperatures while doing their work correctly. Japanese Space Agency (JAXA) has introduced a new concept in the field of graphene-induced solar cells. Instead of believing in the material, they think that taking the solar energy set up closer to the sun will increase its efficiency and 
amount of power production. For this purpose, they launched Space Solar Power System (SSPS) project to place the solar panels in the earth's orbit [147]. Microwaves will help in this regard to transfer power collected from the sunbeam wirelessly. This project is a unique one of its kind and quite handy to produce energy too.

Similarly, implementing graphene-based solar cells in robotics and artificial intelligence can save the workload, time, and pressure of mankind in various ways. Graphene panels and supercapacitors are well known for their efficient energy production. Thus, it can extend the battery life of robots [148]. On the other hand, if these robots are used for agricultural purposes, they will automatically recharge its battery from the exposed sunlight.

The ideal solar power-driven automobile industry had been an exemplary vision for mankind for over a century. Dutch start-up Lightyear first introduced a car that has 400-800 $\mathrm{km}$ range and can charge itself from the sunlight. Eventually, the car showed the capacity to run without being charged for months [149]. After that Toyota Prius range came with the selfrecharging option with 4 miles range, both these aforementioned cars worked underwhelmingly, and the solar-assisted electric automobiles remain completely unexplored till today. The only reason behind this failure of solar-powered cars has been a meager6.4 horsepower rate engine, while a normal lawnmower has 18 horsepower rate engines. Hence these cars become slower than its expectation. The panels used in solar energy-driven cars mainly convert solar energy into electric energy. Hence, it can be concluded that to improve engine capacity. It is much necessary to improve the efficiency and production rate of electrical energy by fabricating graphene matrixed InGaAs alloy solar panels for these automobiles. From the previous discussion, it is clear that graphene is always a superior choice to build an efficient solar panel to help the automobile industry improve its engine capacity if introduced due to some unique chemical and physical characteristics.

Before the emergence of graphene cells, Li-ion batteries were used, but it showed some drawbacks compared to the new generation graphene batteries. Albeit, Lithium Iron Phosphate batteries (LFP) are self-rechargeable batteries; they also have low energy density even though power density is higher than conventional Li batteries. The introduction of graphene in this Libattery makes the setup super light $[150,151]$. Along with it, fast charging capacity and greater efficiency were observed than the normal Li-ion batteries. The driving range and efficiency of electric cars can be improved if graphene-based super-caps are introduced with these ecofriendly cars' Li-ion batteries. Along with the increase of efficiency and capacity introduction of graphene in automobiles, products can also improve the battery's durability. It has been seen that graphene works as a more durable, less expensive, yet most efficient chemical entity in usage than any other alternative energy-producing products available commercially. In 2016, Huawei introduced a sui-generis graphene-enhanced Li battery that could function at high temperatures (near about $60^{\circ} \mathrm{C}$ ) with a longer operational time than conventional $\mathrm{Li}$ batteries [152]. This gives a broad picture that futuristic graphene batteries can sustain high temperatures. According to Xinhua news agency of China, product architect and CEO of Tesla Inc. Elon Musk, acclaimed to upgrade electric model cars by 2022 that will replace the batteries of their conventional Model S Sedan with extra mileage cars equipped with graphene batteries. The next-gen graphene-based electrodes will have quadruple density and output with respect to Li-ion cells [153]. In 2020, Rice University reported the marvelous graphene capability blended with polymer gel $\mathrm{Li}-\mathrm{O}_{2}$ cell that could recharge completely within 20 seconds and retained $90 \%$ capacity after $2000 \mathrm{~h}$ lifetime [154]. 
As air pollution rate propelled and air quality has become hazardous in major cosmopolitan cities, it has serious detrimental effects on human life due to smog. Italcementi recently proposed an extraordinary idea of solving the smog issue by composing graphene$\mathrm{TiO}_{2}$ cement that will have the capability to undergo photocatalysis and dissociate $\mathrm{NO}_{\mathrm{x}}$ formed from smog [155]. The cement is expected to work as conducting walls without the use of wiring systems in the home. Thus, this transfigures modern homes into sustainable eco-houses. The emergence of 3D printing technology has been a revolutionary invention of this decade for manufacturing units, and 3D printed graphene appliances didn't lack behind from emerging in the market. This 3D-printed graphene can provide high capacity work efficiency in the field of batteries, heat management, catalysis, and sensings[156-159]. Hence, it can be undoubtedly established that 3D printed graphene can act as an outstanding futuristic graphene panel. A thin graphene sheet generally remains divided by small air pores, and the 3D representation helps to retain the characteristics of graphene more properly.

\section{Conclusions}

It can be concluded that graphene is one of the most promising chemical entities of this decade. It was beyond humankind's perception that a material discovered from serendipity will be so versatile for modern technical and scientific development. Both its physical and chemical properties can be utilized in every possible way, and graphene can also replace many other chemical entities that are being used successfully for a long time in numerous energy-producing machinery. In some cases, it has been seen that using graphene jointly with other chemical entities improves the efficiency and working capacity of that particular setup. Industrial production has been high, with the whooping global demand for graphene-based commercial products. In photovoltaics, prior graphene, other electron conductors used to be considered the main part of the solar cell; however, with the modification in its feature, graphene has been found to be a promising electrode in solar panels. The newly developed industrial sector procedures plummet its high price, and light weight and corrosion resistive property are highly suitable for photovoltaics. Moreover, this review highlighted the anticipation and expectation this wonder-material might receive in upcoming years. It is glued to terrestrial usage and has reached the experimental trial stage for space voyage and research. It is also expected to bloom in the robotics as well as AI industries soon with its energy-producing ability. Many private companies and research institutes are now giving importance to the R\&D of graphene chemistry to bring more improvements into graphene-induced solar cells to improve efficiency and production. After such successful implementation of graphene electrodes in the solar cell, various other electronic entities are also trying to improvise graphene in their machinery so that the same level of efficiency can also be achieved in those sectors. The introduction of solar cells in the automobile industry will make them an environment-friendly industry. Graphene solar cells in solar cars will help increase their range and speed, which are the most important factors to take care of in the automobile industry. In the short graphene-induced solar cell is the most useful invention of the decade that is getting more attention and development by modern science and research wings worldwide. Scientists are also trying hard to make graphene-based solar cells harvest more energy within less time. By facilitating solar energy, fields' graphene directly promotes clean, sustainable, and environmentally benign energy production and use worldwide. 


\title{
Funding
}

This research received no external funding.

\section{Acknowledgments}

\begin{abstract}
The authors like to thank the Department of Chemistry of NIT Agartala for supporting the work and provided us with valuable technical information.
\end{abstract}

\section{Conflicts of Interest}

The authors declare no conflict of interest.

\section{References}

1. Jennings, P. New directions in renewable energy education. Renew. Energy 2009, 34, 435-439, https://doi.org/10.1016/j.renene.2008.05.005.

2. Panwar, N.; Kaushik, S.; Kothari, S. Role of renewable energy sources in environmental protection: A review. Renew. Sust. Energ. Rev. 2011, 15, 1513-1524, https://doi.org/10.1016/j.rser.2010.11.037

3. Ellabban, O.; Abu-Rub, H.; Blaabjerg, F. J. R.; Reviews, S. E. Renewable energy resources: Current status, future prospects and their enabling technology. Renew. Sust. Energ. Rev. 2014, 39, 748-764, https://doi.org/10.1016/j.rser.2014.07.113

4. Rong, Y.; Hu, Y.; Mei, A.; Tan, H.; Saidaminov, M. I.; Seok, S. I.; McGehee, M. D.; Sargent, E. H.; Han, H., Challenges for commercializing perovskite solar cells. Science 2018, 361, 8235, https://doi.org/10.1126/science.aat8235

5. Hoang, M. H.; Park, G. E.; Choi, S.; Park, C. G.; Park, S. H.; Van Nguyen, T.; Kim, S.; Kwak, K.; Cho, M. J.; Choi, D. H. High-efficiency non-fullerene polymer solar cell fabricated by a simple process using new conjugated terpolymers. J. Mater. Chem. C 2019, 7, 111-118, https://doi.org/10.1039/C8TC05035J

6. Novoselov, K. S.; Geim, A. K.; Morozov, S. V.; Jiang, D.; Zhang, Y.; Dubonos, S. V.; Grigorieva, I. V.; Firsov, A. A. Electric field effect in atomically thin carbon films. Science 2004, 306, 666-669, https://doi.org/10.1126/science.1102896

7. Mandal, P.; Nath, K. K.; Saha, M., Efficient Blue Luminescent Graphene Quantum Dots and their Photocatalytic Ability Under Visible Light. Biointerface Res. Appl. Chem. 2021, 11, 1059-1064, https://doi.org/10.33263/BRIAC111.81718178.

8. Yao, H.; Li, P.; Cheng, W.; Yang, W.; Yang, Z.; Ali, H. P. A.; Guo, H.; Tee, B. C. K. Environment-Resilient Graphene Vibrotactile Sensitive Sensors for Machine Intelligence. ACS Mater. Lett. 2020, 2, 986-992, https://doi.org/10.1021/acsmaterialslett.0c00160

9. Palmieri, V.; Papi, M. Can graphene take part in the fight against COVID-19? Nano Today 2020, 33, 100883.https://doi.org/10.1016/j.nantod.2020.100883

10. Martelli, C.; King, A.; Simon, T.; Giamas, G. J. A. B. S. Graphene-Induced Transdifferentiation of Cancer Stem Cells as a Therapeutic Strategy against Glioblastoma. ACS Biomater. Sci. Eng. 2020, 6, 3258-3269, https://doi.org/10.1021/acsbiomaterials.0c00197

11. Liu, M.; Huang, C.; Jia, Z.; Zhao, Z.; Xiao, X.; Wang, A.; Li, P.; Guan, X.; Zhou, G.; Fan, Y. Promotion of Neuronal Guidance Growth by Aminated Graphene Oxide via Netrin-1/Deleted in Colorectal Cancer Signaling. ACS Chem. Neurosci. 2020, 11, 604-614, https://doi.org/10.1021/acschemneuro.9b00625

12. Lee, I.; Kang, W. T.; Kim, J. E.; Kim, Y. R.; Won, U. Y.; Lee, Y. H.; Yu, W. J. Photoinduced Tuning of Schottky Barrier Height in Graphene/MoS2 Heterojunction for Ultrahigh Performance Short Channel Phototransistor. ACS Nano 2020, 14, 7574-7580, https://doi.org/10.1021/acsnano.0c03425.

13. Kolli, V.; Gadepalli, S.; Debbarma, J.; Mandal, P.; Barathula, S. Experimental analysis on performance, combustion \& emissions of a diesel engine fueled by Aegle marmelos seed oil biodiesel with additives: Graphene Nanosheets and oxygenated diethyl ether. Energ. Source. Part A. 2020, 1-20, https://doi.org/10.1080/15567036.2020.1783393.

14. Agbonlahor, O. G.; Muruganathan, M.; Imamura, T.; Mizuta, H. Adsorbed Molecules as Interchangeable Dopants and Scatterers with a van der Waals Bonding Memory in Graphene Sensors. ACS Sens. 2020, 5 , 2003-2009, https://doi.org/10.1021/acssensors.0c00403 
15. Mandal, P.; Saha, M. Synthesis of Graphene Nanosheets and Photocatalytic Application in Dye Degradation. J. Sci. Ind. Res. 2019, 78, 863-867, http://nopr.niscair.res.in/handle/123456789/52214

16. Xiao, X.; Li, Y.; Liu, Z. Graphene commercialization. Nat. Mater. 2016, 15, 69, https://doi.org/10.1038/nmat4665

17. Xu, X.; Wang, H.; Wang, J.; Muhammad, M.; Wang, Z.; Chen, P.; Zhao, W.; Kang, B.; Zhang, J.; Li, C. Surface Functionalization of a Graphene Cathode to Facilitate ALD Growth of an Electron Transport Layer and Realize High-Performance Flexible Perovskite Solar Cells. ACS Appl. Energy Mater. 2020, 3, 42084216, https://doi.org/10.1021/acsaem.9b02191.

18. Wang, S.; Xie, Y.; Shi, K.; Zhou, W.; Xing, Z.; Pan, K.; Cabot, A. Monodispersed Nickel Phosphide Nanocrystals in Situ Grown on Reduced Graphene Oxide with Controllable Size and Composition as a Counter Electrode for Dye-Sensitized Solar Cells. ACS Sustain. Chem. Eng. 2020, 8, 5920-5926, https://doi.org/10.1021/acssuschemeng.0c00005.

19. Sutradhar, P.; Saha, M. Silver nanoparticles: synthesis and its nanocomposites for heterojunction polymer solar cells. J. Phys. Chem. C 2016, 120, 8941-8949, https://doi.org/10.1021/acs.jpcc.6b00075.

20. Cotet, L. C.; Fort, C. I.; Pop, L. C.; Baia, M.; Baia, L., Insights Into Graphene-Based Materials as Counter Electrodes for Dye-Sensitized Solar Cells. In Dye-Sensitized Solar Cells, Elsevier: 2019; pp 341396.https://doi.org/10.1016/B978-0-12-814541-8.00010-0

21. About Solar Energy and PV Solar Panels | Trina Solar https://www.trinasolar.com/en-glb/ourcompany/innovation (accessed May 16, 2020)

22. Project Development | First Solar http://www.firstsolar.com/PV-Plants/Project-Development (accessed May 18, 2020)

23. Solar Plants Project Development - Canadian Solar https://www.canadiansolar.com/thatcher/detail/269 (accessed May 19, 2020)

24. Hanwha Q CELLS Reports $3^{\text {rd }}$ Quarter 2018 Results https:/www.hanwha-qcells.com/qcellsoffice/about/awards (accessed May 19, 2020)

25. Bhandari, B.; Lim, N., The Dark Side of China's Solar Boom https://www.sixthtone.com/news/1002631/thedark-side-of-chinas-solar-boom- (accessed May 20, 2020)

26. Lakhe, P.; Kulhanek, D. L.; Zhao, X.; Papadaki, M. I.; Majumder, M.; Green, M. J. Graphene Oxide Synthesis: Reaction Calorimetry and Safety. Ind. Eng. Chem. Res. 2020, 59, 9004-9014, https://doi.org/10.1021/acs.iecr.0c00644

27. Graphene mass production, roll to roll - Graphenea https://www.graphenea.com/blogs/graphenenews/8017795-graphene-mass-production-roll-to-roll. (accessed May 20, 2020)

28. Saint Jean Carbon develops hybrid graphene sheets with superconductivity | Graphene-Info https://www.graphene-info.com/saint-jean-carbon-develops-hybrid-graphene-sheets-superconductivity. (accessed May 20, 2020)

29. ZNShine Solar lauches graphene-coating PV series to accelerate cost reduction and efficeincy improvement - ZNShine Solar https:/www.prnewswire.com/news-releases/znshine-solar-launches-graphene-coating-pvseries-to-accelerate-cost-reduction-and-efficiency-improvement-300640895.html. (accessed May 21, 2020)

30. Mao, H. Y.; Lu, Y. H.; Lin, J. D.; Zhong, S.; Wee, A. T. S.; Chen, W. Manipulating the electronic and chemical properties of graphene via molecular functionalization. Prog. Surf. Sci. 2013, 88, 132-159, https://doi.org/10.1016/j.progsurf.2013.02.001

31. Behura, S. K.; Wang, C.; Wen, Y.; Berry, V. Graphene-semiconductor heterojunction sheds light on emerging photovoltaics. Nat. Photonics 2019, 13, 312-318, https://doi.org/10.1038/s41566-019-0391-9.

32. Jeong, G.; Koo, D.; Seo, J.; Jung, S.; Choi, Y.; Lee, J.; Park, H. Suppressed Interdiffusion and Degradation in Flexible and Transparent Metal Electrode-Based Perovskite Solar Cells with a Graphene Interlayer. Nano Lett. 2020, 20, 3718-3727, https://doi.org/10.1021/acs.nanolett.0c00663.

33. Liao, W.; Gao, Y.; Wang, W.; Zuo, X.; Yang, Q.; Lin, Y.; Tang, H.; Jin, S.; Li, G. Boosted Reactivity of Low-Cost Solar Cells over a CuO/Co3O4 Interfacial Structure Integrated with Graphene Oxide. ACS Sustain. Chem. Eng. 2020, 8, 7308-7315, https://doi.org/10.1021/acssuschemeng.0c00282.

34. Mehmood, U.; Asghar, H.; Babar, F.; Younas, M. Effect of graphene contents in polyaniline/graphene composites counter electrode material on the photovoltaic performance of dye-sensitized solar cells (DSSCSs). Sol. Energy 2020, 196, 132-136, https://doi.org/10.1016/j.solener.2019.12.024. 
35. Shang, W.; Wu, F.; Wen, Y.; He, C.; Zhan, X.; Li, Y. Corrosion resistance and mechanism of graphene oxide composite coatings on magnesium alloy. Ind. Eng. Chem. Res. 2018, 58, 1200-1211, https://doi.org/10.1021/acs.iecr.8b05303.

36. Liu, D.; Zhao, W.; Liu, S.; Cen, Q.; Xue, Q. Comparative tribological and corrosion resistance properties of epoxy composite coatings reinforced with functionalized fullerene C60 and graphene. Surf. Coat. Technol. 2016, 286, 354-364, https://doi.org/10.1016/j.surfcoat.2015.12.056.

37. Li, X.; Chen, W.; Zhang, S.; Wu, Z.; Wang, P.; Xu, Z.; Chen, H.; Yin, W.; Zhong, H.; Lin, S. 18.5\% efficient graphene/GaAs van der Waals heterostructure solar cell. Nano Energy 2015, 16, 310-319, https://doi.org/10.1016/j.nanoen.2015.07.003.

38. Chen, H.; Luo, Q.; Liu, T.; Tai, M.; Lin, J.; Murugadoss, V.; Lin, H.; Wang, J.; Guo, Z.; Wang, N. Boosting Multiple Interfaces by Co-Doped Graphene Quantum Dots for High Efficiency and Durability Perovskite Solar Cells. ACS Appl. Mater. Inter. 2020, 12, 13941-13949, https://doi.org/10.1021/acsami.9b23255.

39. Lamanna, E.; Matteocci, F.;Calabrò, E.; Serenelli, L.; Salza, E.; Martini, L.; Menchini, F.; Izzi, M.; Agresti, A.; Pescetelli, S. Mechanically Stacked, Two-Terminal Graphene-Based Perovskite/Silicon Tandem Solar Cell with Efficiency over 26\%. Joule 2020, 4, 865-881, https://doi.org/10.1016/j.joule.2020.01.015.

40. Kumar, D. K.; Swami, S. K.; Dutta, V.; Chen, B.; Bennett, N.; Upadhyaya, H. Scalable screen-printing manufacturing process for graphene oxide platinum free alternative counter electrodes in efficient dye sensitized solar cells. FlatChem 2019, 15, 100105, https://doi.org/10.1016/j.flatc.2019.100105.

41. Shi, Z.; Jayatissa, A. H. The impact of graphene on the fabrication of thin film solar cells: Current status and future prospects. Materials 2018, 11, 36, https://doi.org/10.3390/ma11010036.

42. Mahmoudi, T.; Wang, Y.; Hahn, Y. B. SrTiO3/A12O3-Graphene Electron Transport Layer for Highly Stable and Efficient Composites-Based Perovskite Solar Cells with 20.6\% Efficiency. Adv. Energy Mater. 2020, 10, 1903369, https://doi.org/10.1002/aenm.201903369.

43. S ${ }^{2}$ A's \#GreenLuxHome Will Feature the World's Only Patented Graphene Solar Panel - S2A Modular https://www.s2amodular.com/2020/03/09/s2as-greenluxhome-will-feature-the-worlds-only-patentedgraphene-solar-panel/. (accessed May 24, 2020)

44. Najafi, L.; Taheri, B.; Martín-García, B.; Bellani, S.; Di Girolamo, D.; Agresti, A.; Oropesa-Nunez, R.; Pescetelli, S.; Vesce, L.; Calabro, E. MoS2 quantum dot/graphene hybrids for advanced interface engineering of a CH3NH3PbI3 perovskite solar cell with an efficiency of over 20\%. ACS Nano 2018, 12, 1073610754.https://doi.org/10.1021/acsnano.8b05514.

45. Tsuboi, Y.; Wang, F.; Kozawa, D.; Funahashi, K.; Mouri, S.; Miyauchi, Y.; Takenobu, T.; Matsuda, K.Enhanced photovoltaic performances of graphene/Si solar cells by insertion of a MoS 2 thin film. Nanoscale 2015, 7, 14476-14482, https://doi.org/10.1039/C5NR03046C.

46. Park, H.; Kong, J. An Alternative Hole Transport Layer for Both ITO-and Graphene-Based Organic Solar Cells. Adv. Energy Mater. 2014, 4, 1301280, https://doi.org/10.1002/aenm.201301280.

47. Shi, E.; Li, H.; Yang, L.; Zhang, L.; Li, Z.; Li, P.; Shang, Y.; Wu, S.; Li, X.; Wei, J. Colloidal antireflection coating improves graphene-silicon solar cells. Nano Lett. 2013, 13, 1776-1781, https://doi.org/10.1021/n1400353f.

48. Chandrasekhar, P.; Dubey, A.; Qiao, Q. High efficiency perovskite solar cells using nitrogen-doped graphene/ZnO nanorod composite as an electron transport layer. Sol. Energy 2020, 197, 78-83, https://doi.org/10.1016/j.solener.2019.12.062.

49. Aliprandi, A.; Eredia, M.; Anichini, C.; Baaziz, W.; Ersen, O.; Ciesielski, A.; Samorì, P. Persian waxing of graphite: towards green large-scale production of graphene. Chem. Commun. 2019, 55, 53315334.https://doi.org/10.1039/C9CC01822K.

50. Deng, B.; Liu, Z.; Peng, H. Toward mass production of CVD graphene films. Adv. Mater. 2019, 31, 1800996, https://doi.org/10.1002/adma.201800996.

51. Mandal, P.; Naik, M. J. P.; Saha, M. Room temperature synthesis of graphene nanosheets. Cryst. Res. Technol. 2018, 53, 1700250, https://doi.org/10.1002/crat.201700250.

52. Mandal, P.; Saha, M. Scalable preparation of carbon nanoparticles and graphene nanoflakes using sand paper abrasion. Materialwiss. Werkstofftech. 2020, 51, 902-907.https://doi.org/10.1002/mawe.201900135. 
53. Jacobse, P. H.; McCurdy, R. D.; Jiang, J.; Rizzo, D. J.; Veber, G.; Butler, P.; Zuzak, R.; Louie, S. G.; Fischer, F. R.; Crommie, M. F. Bottom-up Assembly of Nanoporous Graphene with Emergent Electronic States. $J$. Am. Chem. Soc. 2020, 142, 13507-13514.https://doi.org/10.1021/jacs.0c05235.

54. Pawlak, R.; Liu, X.; Ninova, S.; d'Astolfo, P.; Drechsel, C.; Sangtarash, S.; Häner, R.; Decurtins, S.; Sadeghi, H.; Lambert, C. J. Bottom-up Synthesis of Nitrogen-doped Porous Graphene Nanoribbons. J. Am. Chem. Soc. 2020, 142, 12568-12573, https://doi.org/10.1021/jacs.0c03946.

55. Yoon, K.-Y.; Dong, G. Liquid-phase bottom-up synthesis of graphene nanoribbons. Mater. Chem. Front. 2020,4, 29-45, https://doi.org/10.1039/C9QM00519F.

56. Wang, X.-Y.; Urgel, J. I.; Barin, G. B.; Eimre, K.; Di Giovannantonio, M.; Milani, A.; Tommasini, M.; Pignedoli, C. A.; Ruffieux, P.; Feng, X. Bottom-up synthesis of heteroatom-doped chiral graphene nanoribbons. J. Am. Chem. Soc. 2018, 140, 9104-9107, https://doi.org/10.1021/jacs.8b06210.

57. Mandal, P.; Debbarma, J.; Saha, M. One Step Synthesis of N-Containing Graphene Oxide from 3Aminophenol. Cryst. Res. Technol. 2020, 55, 1900158, https://doi.org/10.1002/crat.201900158.

58. Mandal, P.; Saha, M. Low-temperature synthesis of graphene derivatives: mechanism and characterization. Chem. Pap. 2019,73, 1997-2006, https://doi.org/10.1007/s11696-019-00756-3.

59. Debbarma, J.; Mandal, P.; Saha, M., Chemistry and Mechanism of One-Step Formation of Graphene from Agrowaste. Lett. Appl. NanoBioScience 2020, 9, 1389-1394, https://doi.org/10.33263/LIANBS93.13891394.

60. Stanford, M. G.; Li, J. T.; Chyan, Y.; Wang, Z.; Wang, W.; Tour, J. M. Laser-induced graphene triboelectric nanogenerators. ACS Nano 2019, 13, 7166-7174, https://doi.org/10.1021/acsnano.9b02596.

61. Stanford, M. G.; Zhang, C.; Fowlkes, J. D.; Hoffman, A.; Ivanov, I. N.; Rack, P. D.; Tour, J. M. HighResolution Laser-Induced Graphene. Flexible Electronics beyond the Visible Limit. ACS Appl. Mater. Inter. 2020, 12, 10902-10907, https://doi.org/10.1021/acsami.0c01377.

62. Li, X.; Xie, D.; Park, H.; Zeng, T. H.; Wang, K.; Wei, J.; Zhong, M.; Wu, D.; Kong, J.; Zhu, H. Anomalous behaviors of graphene transparent conductors in graphene-silicon heterojunction solar cells. Adv. Energy Mater. 2013, 3, 1029-1034, https://doi.org/10.1002/aenm.201300052.

63. Castellanos-Gomez, A. Why all the fuss about 2D semiconductors? Nat. Photonics 2016, 10, 202-204, https://doi.org/10.1038/nphoton.2016.53.

64. Bafekry, A.; Neek-Amal, M. Tuning the electronic properties of graphene-graphitic carbon nitride heterostructures and heterojunctions by using an electric field. Phys. Rev. B 2020, 101, 085417, https://doi.org/10.1103/PhysRevB.101.085417.

65. Saranya, M.; Ayyappan, S.; Nithya, R.; Sangeetha, R.; Gokila, A. Molecular structure, NBO and HOMOLUMO analysis of quercetin on single layer graphene by density functional theory. Dig. J. Nanomater. Bios. 2018, 13, 97-105.

66. Zhang, Y. J.; Zhang, Y. X.; Yang, M. Y. Synthesis of environment-friendly graphene reinforced slag-based nanocomposite and performance of photocatalytic $\mathrm{H}_{2}$ generation. Ferroelectrics 2018, 522, 36-44, https://doi.org/10.1080/00150193.2017.1391609.

67. Satou, A.; Ryzhii, V.; Kurita, Y.; Otsuji, T. Threshold of terahertz population inversion and negative dynamic conductivity in graphene under pulse photoexcitation. J. Appl. Phys. 2013, 113, 143108, https://doi.org/10.1063/1.4801916.

68. Lee, S.-M.; Kim, J.-H.; Ahn, J.-H., Graphene as a flexible electronic material: mechanical limitations by defect formation and efforts to overcome. Mater. Today 2015, 18, 336-344, https://doi.org/10.1016/j.mattod.2015.01.017.

69. Goldsche, M.; Sonntag, J.; Khodkov, T.; Verbiest, G. J.; Reichardt, S.; Neumann, C.; Ouaj, T.; von den Driesch, N.; Buca, D.; Stampfer, C. Tailoring mechanically tunable strain fields in graphene. Nano Lett. 2018, 18, 1707-1713, https://doi.org/10.1021/acs.nanolett.7b04774.

70. Zhao, X.; Tao, L.; Li, H.; Huang, W.; Sun, P.; Liu, J.; Liu, S.; Sun, Q.; Cui, Z.; Sun, L. Efficient planar perovskite solar cells with improved fill factor via interface engineering with graphene. Nano Lett. 2018, 18, 2442-2449, https://doi.org/10.1021/acs.nanolett.8b00025.

71. Velasco Jr, J.; Lee, Y.; Zhang, F.; Myhro, K.; Tran, D.; Deo, M.; Smirnov, D.; MacDonald, A. H.; Lau, C. Competing ordered states with filling factor two in bilayer graphene. Nat. Commun. 2014, 5, 4550, https://doi.org/10.1038/ncomms5550. 
72. De Fazio, D.; Purdie, D. G.; Ott, A. K.; Braeuninger-Weimer, P.; Khodkov, T.; Goossens, S.; Taniguchi, T.; Watanabe, K.; Livreri, P.; Koppens, F. H. High-mobility, wet-transferred graphene grown by chemical vapor deposition. ACS Nano 2019, 13, 8926-8935, https://doi.org/10.1021/acsnano.9b02621.

73. Hirai, H.; Tsuchiya, H.; Kamakura, Y.; Mori, N.; Ogawa, M. Electron mobility calculation for graphene on substrates. J. Appl. Phys. 2014, 116, 083703, https://doi.org/10.1063/1.4893650.

74. Li, H.; Han, X.; Childress, A. S.; Rao, A. M.; Koley, G. Investigation of carrier density and mobility variations in graphene caused by surface adsorbates. Physica E: Low-dimens. Sys. Nanostruct. 2019, 107, 96-100, https://doi.org/10.1016/j.physe.2018.11.021.

75. Balandin, A. A. Phononics of graphene and related materials. ACS Nano 2020, 14, 5170-5178, https://doi.org/10.1021/acsnano.0c02718.

76. Wu, X.; Xing, Y.; Zeng, K.; Huber, K.; Zhao, J. X. Study of fluorescence quenching ability of graphene oxide with a layer of rigid and tunable silica spacer. Langmuir 2018, 34, 603611.https://doi.org/10.1021/acs.langmuir.7b03465.

77. Ortiz-Torres, M. I.; Fernández-Niño, M.; Cruz, J. C.; Capasso, A.; Matteocci, F.; Patiño, E. J.; Hernández, Y.; Barrios, A. F. G. Rational Design of photo-electrochemical Hybrid Devices Based on Graphene and Chlamydomonas reinhardtii Light-Harvesting proteins. Sci. Rep. 2020, 10, 1-11, https://doi.org/10.1038/s41598-020-60408-5.

78. Wang, H. X.; Wang, Q.; Zhou, K. G.; Zhang, H. L. Graphene in Light: Design, Synthesis and Applications of Photo-active Graphene and Graphene-Like Materials. Small 2013, 9, 12661283.https://doi.org/10.1002/smll.201203040.

79. Pattarith, K.; Areerob, Y. Fabrication of Ag nanoparticles adhered on RGO based on both electrodes in dyesensitized solar cells (DSSCs). Renewables: Wind, Water, Solar 2020, 7, 110.https://doi.org/10.1186/s40807-020-00058-3.

80. Mustaffa, N.; Rahman, M.; Umar, A. Dye-sensitized solar cell utilizing silver doped reduced graphene oxide films counter electrode: Influence of annealing temperature on its performance. Arab. J. Chem. 2020, 13, 3383-3390, https://doi.org/10.1016/j.arabjc.2018.11.012.

81. Rahman, M.; Sulaiman, A.; Umar, A., Dye-sensitized Solar Cell utilizing Gold Doped Reduced Graphene Oxide Films Counter Electrode. J. New Mat. Electr. Sys. 2018, 21, 113-117, https://doi.org/10.14447/jnmes.v21i2.466.

82. Ju, S.; Liang, B.; Wang, J.-Z.; Shi, Y.; Li, S.-L., Graphene/silicon Schottky solar cells: Technical strategies for performance optimization. Opt. Commun. 2018, 428, https://doi.org/10.1016/j.optcom.2018.02.033.

83. Tsai, K.-A. Hsieh, P.-Y.; Lai, T.-H.; Tsao, C.-W.; Pan, H.; Lin, Y.-G.; Hsu, Y.-J. Nitrogen-doped Graphene Quantum Dots for Remarkable Solar Hydrogen Production. ACS Appl. Energy Mater. 2020, 3, 5322-5332, https://doi.org/10.1021/acsaem.0c00335.

84. Guo, C. X.; Yang, H. B.; Sheng, Z. M.; Lu, Z. S.; Song, Q. L.; Li, C. M. Layered graphene/quantum dots for photovoltaic devices. Angew. Chem. Int. 2010, 49, 3014-3017, https://doi.org/10.1002/anie.200906291.

85. Majumder, T.; Mondal, S. P. Graphene quantum dots as a green photosensitizer with carbon-doped $\mathrm{ZnO}$ nanorods for quantum-dot-sensitized solar cell applications. Bull. Mater. Sci. 2019, 42, 65, https://doi.org/10.1007/s12034-019-1755-y.

86. Transparent, flexible solar cells | MIT News |Massachusetts Institute of Technology, https://news.mit.edu/2017/mit-researchers-develop-graphene-based-transparent-flexible-solar-cells0728(accessed April1, 2021)

87. BM 300T: Deposition System for Carbon nanomaterials: AIXTRON https://www.aixtron.com/en/products/2d-nanotechnology-pecvd/bm-300t. (accessed May 29, 2020)

88. ZNShine Solar to supply graphene-enhanced PV modules to India's BHEL | Graphene-Info https://www.graphene-info.com/znshine-solar-supply-graphene-enhanced-pv-modules-indias-bhel. (accessed May 30, 2020)

89. China Carbon Graphite Group Inc. http://chinacarboninc.com/ (accessed May 30, 2020)

90. Elcora Graphite and Graphene Advanced Material Production https://www.elcoracorp.com/products/. (accessed May 30, 2020)

91. Puregraph - First Graphene https://firstgraphene.net/puregraph/. (accessed May 30, 2020) 
92. Mesograf ${ }^{\text {TM }}$ Graphene | Low-Cost, Near-Pristine and Environmentally Safe https://www.grafoid.com/mesograf-graphene/. (accessed May 30, 2020)

93. Saint Jean Carbon: Anode Material. http://saintjeancarbon.com/graphene-lithium-ion-battery.html. (accessed April1, 2021)

94. Automotive Application - Haydale https://haydale.com/case_studies/automotive-application/. (accessed May 30, 2020)

95. Overview | Graphene NanoChem http://www.graphenenanochem.com/business-segments/advancedmaterials/overview. (accessed May 30, 2020)

96. Magwood, L. Jr.; Ali, B. Spherical polymeric particle containing graphene nanoplatelets as three dimensional printing precursor. U.S. Patent 16, 668, 564, April 30, 2020.

97. Fukushima, H.; Ritch, T.; Russell, J.; Wang, L. 2-dimensional thermal conductive materials and their use. U.S. patent 10, 568, 544, Feb 24, 2020.

98. Zhong, H.; Zhu, Z.; Lin, J.; Cheung, C. F.; Lu, V. L.; Yan, F.; Chan, C.-Y.; Li, G. Reusable and recyclable graphene masks with outstanding superhydrophobic and photothermal performances. ACS Nano 2020, 14, 6213-6221, https://doi.org/10.1021/acsnano.0c02250.

99. Versarien plc - Developing advanced materials and enabling engineering exploration http://www.versarien.com/. (accessed May 31, 2020)

100.Kornilov, D. Y.; Gubin, S.; Chuprov, P.; Rychagov, A. Y.; Cheglakov, A.; Karaseva, A.; Krasnova, E.; Voronov, V.; Tkachev, S.; Kasharina, L. Reduced graphene oxide as a protective layer of the current collector of a lithium-ion battery. Russ. J. Electrochem. 2017, 53, 622-626, https://doi.org/10.1134/S102319351706012X

101.Kong, W.; Kum, H.; Bae, S.-H.; Shim, J.; Kim, H.; Kong, L.; Meng, Y.; Wang, K.; Kim, C.; Kim, J., Path towards graphene commercialization from lab to market. Nat. Nanotechnol. 2019, 14, 927-938, https://doi.org/10.1038/s41565-019-0555-2.

102.Vivanco, J. P.; Rodriguez-Monroy, C. Graphene Applications in the Energy Field: State-of-the-Art and Impact; 2516-2314; EasyChair: 2018.

103.MediaDevil Artisanphonics CB-01 graphene-enhanced wood earphones https://mediadevil.com/products/artisanphonics-cb-01-nanene-graphene-wood-earphones. (accessed May $31,2020)$

104.RM 50-03 - RICHARD MILLE | Manual Winding Tourbillon Split-Seconds Chronograph McLaren F1 https://www.richardmille.com/collections/rm-50-03-tourbillon-chronograph-mclaren-f1. (accessed May 31, 2020)

105.Nanomedical diagnostics Agile R100 Graphene Biosensor characterizes Oncoprotein https://www.prweb.com/releases/nanomedical_diagnostics_agile_r100_graphene_biosensor_characterizes_ difficult_to_study_myc_oncoprotein_for_cancer_research/prweb15675304.htm (accessed May 31, 2020)

106. Catlike Mixino helmet https://bumsonthesaddle.com/products/catlike-road-helmet-mixino (accessed May 31, 2020)

107.Graphene 2.0: the best upgraded - Vittoria https://www.vittoria.com/ap/graphene2_0?__store=ap_en\&_from_store=ap_en (accessed May 31, 2020)

108.Graphene-Colmar: https://www.colmar.it/int/ski-pants-with-graphene-lining/04347VCIN20504.html (accessed April 1, 2021)

109.ClimaCoomand Classic Seat, Black | Indian Motorcyle https://www.indianmotorcycle.com/enus/shop/accessories/seats-backrests/2884419-vba/ (accessed May 31, 2020)

110. California Lithium battery - Transforming the Way Energy is stored https://clbattery.com/ (accessed May 31, 2020)

111.HELLA Graphene Engine Oil Additives $250 \quad \mathrm{ml} \quad-\quad$ 11STREET http://global.11st.co.kr/glb/product/SellerProductDetail.tmall?method=getSellerProductDetail\&prdNo=236 0004695 (accessed May 31, 2020)

112.VIS-SWIR-Emberion https://www.emberion.com/products/vis-swir/ (accessed May 31, 2020)

113.Nanocase | Features https://nanocase.com/features.html (accessed May 31, 2020)

114.Anker | Zolo Liberty [Upgraded] True-Wireless headphones https://www.anker.com/products/variant/zololiberty-[upgraded]-truewireless-headphones/Z2001011(accessed May 31, 2020)

115.Mi Global Home https://www.mi.com/global/headphonesprohd (accessed May 31, 2020)

116. Huawei Mate 20 X - Huawei Global https://consumer.huawei.com/en/phones/mate20-x/ (accessed May 31, 2020)

https://biointerfaceresearch.com/ 
117.FiiO F3 Dynamic In-ear Monitors - Reviews | Headphones Review and Discussions https://www.headfi.org/showcase/fiio-f3-dynamic-in-ear-monitors.22203/reviews (accessed May 31, 2020)

118. Galapad Settler - the first smartphone made from graphene https://en.gizchina.it/2015/03/arrivo-dalla-cinail-galapad-settler-primo-smartphone-realizzato-con-il-grafene/ (accessed May 31, 2020)

119.Products - GrapheneTech http://www.graphene-tech.net/products/ (accessed May 31, 2020)

120.Cardea Zero Z340 M.2 PCIe SSD | TeamGroup https://www.teamgroupinc.com/en/product/cardea-zero-z340 (accessed May 31, 2020)

121.absoluteBLACK | Graphenlube worlds best chain lubricant coating https://absoluteblack.cc/graphenlubeworlds-best-chain-lubricant-coating/ (accessed May 31, 2020)

122.Dassi Interceptor Graphene Bike 50cm | Durasport https://www.durasport.com.sg/product/dassi-interceptorgraphene-bike-1-2/ (accessed May 31, 2020)

123.Graphene Supercapacitors |https://www.m-solv.com/news-post/graphene-supercapacitors. (accessed May $31,2020)$

124.Graphene XT https://www.head.com/en-IC/sports/tennis/technology/graphene-xt/ (accessed May 31, 2020)

125.Sensors | QSense https://www.biolinscientific.com/qsense/sensors (accessed May 31, 2020)

126. Grays Hockey | GR Composites Hockey Sticks https://www.grays-hockey.com/collections/gr-compositehockey-sticks (accessed June 2, 2020)

127. Standard Genable dispersions - Applied Graphene Mateerials plc, https://www.appliedgraphenematerials.com/wp-content/uploads/2020/08/Genable_1000_TDS_V2.0.pdf (accessed June 2, 2020)

128. Iterchimica Srl | High-tech additives for the road industry, https://iterchimica.it/en/ (accessed June 2, 2020)

129.FGTR Graphene 1.0 - en.momodesign.com https://en.momodesign.com/products/fgtr-graphene-1-0 (accessed June 2, 2020)

130.Graphene sunglasses - NRC, https://www.gambacicli.com/en/nrc-x1-everest-sph-photochromic-cyclingglasses.html (accessed April 1, 2021)

131.G-Series - Graphene-enhanced Running \& Training Shoes | inov-8 https://www.inov-8.com/us/g-series (accessed June 2, 2020)

132.Features - Freshoes https://freshoes.it/features/?lang=en (accessed June 2, 2020)

133.Lamborghini Terzo Millenio | Lamborghini.com https://www.lamborghini.com/en-en/models/concept/terzomillennio (accessed June 3, 2020)

134.Advantages and Disadvantages of Graphene | Stanford Advanced Materials https://samaterials.wordpress.com/2014/03/27/advantages-and-disadvantages-of-graphene/ (accessed June 3, 2020)

135.Ferguson, V.; Silva, S. R. P.; Zhang, W. Carbon materials in perovskite solar cells: prospects and future challenges. Energy Environ. Mater. 2019, 2, 107-118, https://doi.org/10.1002/eem2.12035.

136.Liu, P.; Liu, J.; Zhang, B.; Zong, W.; Xu, S.; Liu, Y.; Cao, S. Enhanced electroluminescent performance by doping organic conjugated ionic compound into graphene oxide hole-injecting layer. J. Mater. Sci. 2019, 54, 12688-12697, https://doi.org/10.1007/s10853-019-03820-1.

137.Chen, M.; Wang, Y.; Ma, W.; Huang, Y.; Zhao, Z. Ionic Liquid Gating Enhanced Photothermoelectric Conversion in Three-Dimensional Microporous Graphene. ACS Appl. Mater. Interfaces 2020, 12, 2851028519, https://doi.org/10.1021/acsami.0c05833.

138.Jang, C. W.; Kim, J. M.; Choi, S.-H. Lamination-produced semi-transparent/flexible perovskite solar cells with doped-graphene anode and cathode. J. Alloys Comp. 2019, 775, 905-911, https://doi.org/10.1016/j.jallcom.2018.10.190.

139.About Fraunhofer ISE - Fraunhofer ISE https://www.ise.fraunhofer.de/en/about-us.html. (accessed June 5, 2020)

140.Electric Cars, Solar \& Clean Energy | Tesla https://www.tesla.com/. (accessed June 5, 2020)

141.Graphene's versatility extends to space applications https://www.nanowerk.com/nanotechnologynews2/newsid=51904.php. (accessed June 5, 2020)

142.Home Thales https://www.thalesgroup.com/en. (accessed June 5, 2020)

143. Graphene enters the stratosphere https://phys.org/news/2018-08-graphene-stratosphere.html. (accessed June 5, 2020)

144.Leovy, C. Weather and climate on Mars. Nature 2001, 412, 245-249, https://doi.org/10.1038/35084192. 
145. Voosen, P. Martian chronicler. Science $\mathbf{2 0 2 0 ,}$ 368, 1416-1421, https://doi.org/10.1126/science.368.6498.1416.

146.Civiš, S.; Knížek, A.; Rimmer, P. B.; Ferus, M.; Kubelík, P.; Zukalová, M. t.; Kavan, L.; Chatzitheodoridis, E. Formation of Methane and (Per) Chlorates on Mars. ACS Earth Space Chem. 2018, 3, 221-232. https://doi.org/10.1021/acsearthspacechem.8b00104.

147.JAXA | Japan Aerospace Exploration Agency https://global.jaxa.jp/. (accessed June 5, 2020)

148.Dewi, T.; Risma, P.; Oktarina, Y.; Roseno, T.; Handayani, A. S.; Wijanarko, Y.; Yudha, H. M. In A Survey on Solar Cell; The Role of Solar Cell in Robotics and Robotics Application in Solar Cell Industry, Proceeding Forum in Research, Science, and Technology (FIRST) 2016, Politeknik Negeri Sriwijaya: 2016

149.Lightyear One | The electric car that charges itself with sunlight | Lightyear https://lightyear.one/lightyearone/. (accessed June 5, 2020)

150.Fang, R.; Chen, K.; Yin, L.; Sun, Z.; Li, F.; Cheng, H. M. The Regulating Role of Carbon Nanotubes and Graphene in Lithium-Ion and Lithium-Sulfur Batteries. Adv. Mater. 2019, 31, 1800863, https://doi.org/10.1002/adma.201800863.

151. Chang, C.; Yin, S.; Xu, J., Exploring high-energy and mechanically robust anode materials based on doped graphene for lithium-ion batteries: a first-principles study. RSC Adv. 2020, 10, 13662-13668, https://doi.org/10.1039/D0RA01086C.

152. Huawei achieves major breakthrough in graphene-assisted High Temperature Li-ion batteries | Huawei Press Centre https://www.huawei.com/en/news/2016/12/Graphene-Assisted-Li-ion-Batteries. (accessed June 5, 2020)

153.Elon Musk may use 'Wonder-material' graphene to push Tesla to next level https://www.businessinsider.in/Elon-Musk-May-Use-The-Wonder-Material-Graphene-To-Push-TeslaPerformance-To-The-Next-Level/articleshow/40874001.cms. (accessed June 6, 2020)

154.Ren, M.; Zhang, J.; Zhang, C.; Stanford, M. G.; Chyan, Y.; Yao, Y.; Tour, J. M. Quasi-Solid-State Li-O2 Batteries with Laser-Induced Graphene Cathode Catalysts. ACS Appl. Energy Mater. 2020,3, 1702-1709. https://doi.org/10.1021/acsaem.9b02182.

155.Borgarello, E., Italcementi Blog https://blog.italcementi.it/it/il-calcestruzzo-intelligente-che-conduceelettricita-la-rivoluzione-del-grafene-entra-nel-settore-delle-costruzioni. (accessed June 8, 2020)

156.Foster, C. W.; Down, M. P.; Zhang, Y.; Ji, X.; Rowley-Neale, S. J.; Smith, G. C.; Kelly, P. J.; Banks, C. E. 3D printed graphene based energy storage devices. Sci. Rep. 2017, 7, 42233. https://doi.org/10.1038/srep42233.

157.Novotný, F.; Urbanová, V.; Plutnar, J.; Pumera, M. Preserving Fine Structure Details and Dramatically Enhancing Electron Transfer Rates in Graphene 3D-Printed Electrodes via Thermal Annealing: Toward Nitroaromatic Explosives Sensing. ACS Appl. Mater. Interfaces 2019, 11, 35371-35375, https://doi.org/10.1021/acsami.9b06683.

158. Browne, M. P.; Novotný, F.; Sofer, Z. k.; Pumera, M. 3D printed graphene electrodes' electro-chemical activation. ACS Appl. Mater. Interfaces 2018,10, 40294-40301, https://doi.org/10.1021/acsami.8b14701.

159.Li, G.; Mo, X.; Law, W.-C.; Chan, K. C. 3D printed graphene/nickel electrodes for high areal capacitance electro-chemical storage. J. Mater. Chem. A 2019, 7, 4055-4062, https://doi.org/10.1039/C8TA11121A. 